\title{
DEFENSOR DEL PUEBLO Y JUSTICIA CONSTITUCIONAL: ENTRE LA DECLARACIÓN DE INTENCIONES Y EL EXCESO COMPETENCIAL
}

\author{
MARÍA DÍAZ CREGO \\ Profesora Ayudante Doctora de Derecho Constitucional \\ Universidad de Alcalá
}

\begin{abstract}
SUMARIO
I. Introducción.

II. La legitimación del Defensor del Pueblo ante el Tribunal Constitucional: un panorama de Derecho Comparado.

III. La legitimación activa del Defensor del Pueblo para plantear el recurso de inconstitucionalidad ante el Tribunal Constitucional: el exceso competencial.

IV. La legitimación activa del Defensor del Pueblo para plantear el recurso de amparo ante el Tribunal Constitucional: la declaración de intenciones.

V. A modo de conclusiones.
\end{abstract}

\section{INTRODUCCIÓN}

El Ombudsman, concebido como un comisionado del Parlamento, que actúa de forma independiente, controlando la observancia del Derecho por las autoridades públicas, nace en Suecia a comienzos del siglo XIX, como muchos autores se han encargado de explicar ${ }^{1}$. Los Ombudsmen suecos, proto-

* Este trabajo ha sido realizado con el apoyo de la Defensoría del Pueblo español, que me ha facilitado amplia documentación sobre su actividad, de modo que quiero agradecer a la institución su disponibilidad y colaboración.

1 Entre otros, ver: CARBALlO ARMAS, P.: El Defensor del Pueblo. El Ombudsman en España y en el Derecho Comparado, Tecnos, Madrid, 2003; FAIRÉN GUILLÉN, V.: El defensor del pueblo. Ombudsma, Centro de Estudios Constitucionales, Madrid, 1982. 
tipo histórico de la institución que se extendería después por medio mundo, centran su actividad en el control de la actividad de las autoridades públicas a partir de las quejas recibidas por los administrados o por propia iniciativa, actuando así como una suerte de mediador entre la administración y los ciudadanos. Tras la investigación correspondiente, los Ombudsmen emiten opiniones no vinculantes sobre la posible violación de la legalidad vigente o de los principios de imparcialidad y objetividad; pueden decidir recordar a las autoridades sus deberes legales o sugerirles la modificación de una norma, incluso de rango legal; o pueden iniciar un proceso contra aquellos funcionarios que hayan cometido algún delito en el ejercicio de sus funciones.

La Constitución española configura al Defensor del Pueblo español de una forma similar: el artículo 54 del texto constitucional español define al Defensor del Pueblo como el alto comisionado de las Cortes Generales para la defensa de los derechos reconocidos en el Título I de la Constitución, para lo que podrá "supervisar la actividad de la Administración, dando cuenta a las Cortes Generales". El texto constitucional español vuelve a hacer referencia al Defensor del Pueblo en sus artículos 70 y 162, en los que se prevé la incompatibilidad de los cargos de Diputado y Senador con el de Defensor del Pueblo, y la legitimación del Defensor para interponer recursos de amparo e inconstitucionalidad ante el Tribunal Constitucional.

A pesar de que la configuración de las funciones del Defensor del Pueblo y el Ombudsman sueco parece poner el énfasis en un elemento distinto - la garantía de los derechos fundamentales, en el caso del Defensor del Pueblo español, y el control de la Administración, en el caso sueco² - las facultades de ambas instituciones no divergen significativamente, de modo que el Defensor español también está facultado para controlar el actuar de las Administraciones públicas bien de oficio o a instancia de parte, y para emitir opiniones no vinculantes sobre el respeto de los derechos fundamentales y de los principios del artículo 103.3 de la Constitución por las Administraciones Públicas investigadas. Estas facultades son, por los demás, comunes a la mayoría de las instituciones que la doctrina identifica como aquellas que definen a cualquier Ombudsman ${ }^{3}$.

Sin embargo, el Defensor del Pueblo español ha sido investido de otras facultades que no siempre se atribuyen a instituciones semejantes, en la medida en que, tal y como ha quedado indicado, el artículo 162 de la Constitución española le legitima para interponer ciertos recursos ante el Tribunal Constitucional, en concreto, los recursos de amparo y de inconstitucionalidad. El presente trabajo pretende centrar su atención en esas atribuciones, realizando una valoración de las mismas a partir de un estudio de Derecho Comparado limi-

2 En este sentido: PÉREZ CALVO, A.: "Rasgos esenciales del Defensor del Pueblo según la Constitución y la Ley Orgánica 3/1981, de 6 de abril", Revista de Derecho Político, núm. 11, 1981, págs. 71 y ss.

3 En este sentido, ver: ROWAT, D. C.: El ombudsman: el defensor del ciudadano, Fondo de Cultura Económica, México, 1973, pág. 39; CARBALLO ARMAS, P.: op. cit., págs. 49 y ss. 
tado a los Estados miembros de la Unión Europea y ciertos Estados Latinoamericanos y del análisis de los motivos que justificaron la atribución de esas facultades a nuestro Defensor del Pueblo, de la configuración constitucional y legal de esas atribuciones, y del uso que de ellas ha hecho el Defensor del Pueblo español.

\section{LA LEGITIMACIÓN DEL DEFENSOR DEL PUEBLO ANTE EL TRIBUNAL CONSTITUCIONAL: UN PANORAMA DE DERECHO COMPARADO}

A pesar de que se ha afirmado que la atribución al Defensor del Pueblo español de la competencia para plantear recursos de amparo y de inconstitucionalidad es una facultad extraordinaria y prácticamente inédita ${ }^{4}$, la realidad es que varios ordenamientos de nuestro entorno atribuyen estas facultades a la Defensoría del Pueblo de su país.

Si bien es cierto que la mayoría de los ordenamientos de nuestros vecinos de Europa occidental no atribuyen al Defensor del Pueblo locus standi ante el Tribunal Constitucional respectivo en proceso alguno, esa realidad se transforma si fijamos nuestra mirada en Estados de Europa oriental o de América Latina, donde es relativamente frecuente que la Defensoría del Pueblo pueda plantear algún recurso ante la Corte Constitucional.

Entre los países de Europa occidental, tan sólo Portugal y Austria, junto a España, atribuyen al Ombudsman respectivo la facultad de acudir ante el Tribunal Constitucional. El Provedor de Justiça portugués está facultado para instar ante el Tribunal Constitucional la inconstitucionalidad de cualquier norma e incluso para plantear una eventual inconstitucionalidad por omisión ${ }^{5}$. El Volksanwaltschaft austriaco tiene unas facultades más limitadas, en la medida en que sólo podrá impugnar ante el Tribunal Constitucional austriaco las normas de carácter reglamentario aprobadas por las autoridades federales, pero en ningún caso las leyes adoptadas por el poder legislativo ${ }^{6}$; que sí podrán, sin embargo, ser impugnadas directamente por un particular en casos muy concretos?

4 CARBAllo ARMAS, P.: op. cit., pág. 158.

5 Arts. 281 y 283 de la Constitución portuguesa (http://www.portugal.gov.pt/pt/GC18/Portugal/SistemaPolitico/Constituicao/Pages/default.aspx). Sobre estas facultades: CARBALLO ARMAS P.: op. cit., págs. 111 y ss.; KOFLER, B.: «Portugal”, en KUCSKO-STADLMAYER, G. (ed.): European Ombudsman-Institutions, Springer-Verlad, Viena, 2008, págs. 351 y ss.; FONTANA, G.: "La giustizia costituzionale in Portogallo", en OLIVETTI, M., y GROPPI, T. (dirs): La giustizia costituzionale in Europa, Giuffrè, Milán, 2003, págs. 179 y ss.

6 Arts. 139 y 148 e de la Constitución austriaca (http://www.vfgh.gv.at/cms/vfgh-site/ english/index.html). Sobre el modelo austriaco: KOFLER, B.: "Austria", en KUCSKO-STADLMAYER, G. (ed.): op. cit., págs. 91 y ss.; OLIVETTI, M.: "La giustizia costituzionale in Austria", en OLIVETTI, M., y GROPPI, T. (dirs): op. cit., págs. 25 y ss.

7 Art. 140.1 de la Constitución austriaca. Sobre los supuestos en que cabe el planteamiento de un recurso por un particular, ver: OLIVETTI, M.: op. cit., págs. 59 y ss. 
Sin embargo, en Europa del Este y Latinoamérica, la facultad del Defensor del Pueblo de plantear recursos ante el Tribunal Constitucional está mucho más extendida. Entre los Estados miembros de la Unión Europea ${ }^{8}$, Hungría 9 , Polonia $^{10}$, Rumania ${ }^{11}$, Estonia ${ }^{12}$ y Letonia $^{13}$, reconocen la competencia del Ombudsman respectivo para plantear la inconstitucionalidad de una ley o de una norma de idéntico rango ante el Tribunal Constitucional. En América Latina, los Defensores del Pueblo de Bolivia ${ }^{14}$, Costa Rica ${ }^{15}$, Ecuador ${ }^{16}$, El Salva-

8 Una valoración de las facultades atribuidas a los Defensores del Pueblo de otros países europeos, que no forman parte de la Unión Europea, puede encontrarse en: KUCSKO-STADLMAYER, G. (ed.): op. cit., especialmente, págs. 51 y ss.

9 Para todas las referencias a las atribuciones del Ombudsman húngaro, ver: Art. 22 de la Ley LIX 1993, Law on the Parliamentary Commissioner for Civil Rights y art. 1 Act on the Constitutional Court ( $h t t p: / / w w w . m k a b . h u / i n d e x . p h p ? i d=i n t r o d u c t i o n)$. Sobre las competencias del Defensor del Pueblo del país: STERN, J.: "Hungary", en KUCSKO-STADLMAYER, G. (ed.): op. cit., págs. 221 y ss.

10 Para todas las referencias a las atribuciones del Ombudsman polaco, ver: Arts. 79, 188 y 191 de la Constitución polaca (http://www.sejm.gov.pl/prawo/konst/angielski/kon1.htm). Sobre las competencias del Defensor del Pueblo del país: STERN, J.: "Poland", en KUCSKOSTADLMAYER, G. (ed.): op. cit., págs. 341 y ss.

11 Art. 146 de la Constitución rumana (http://www.cdep.ro/pls/dic/site.page?den= act2_2\&par1=5\#t5c0s0a142), que reconoce al Defensor del pueblo incluso la facultad para plantear un recurso de inconstitucionalidad contra una ley antes de su promulgación. Sobre las competencias del Defensor del Pueblo del país, ver: STERN, J.: "Romania", en KUCSKOSTADLMAYER, G. (ed.): op. cit., págs. 357 y ss.

12 Para todas las referencias a las atribuciones del Ombudsman estonio, ver: Arts. 139 y ss. de la Constitución estonia (http://www.president.ee/en/estonia/constitution.php). Sobre las facultades del Defensor del Pueblo de Estonia, ver: STERN, J.: "Estonia", en KUCSKO-STADLMAYER, G. (ed.): op. cit., págs. 161 y ss.

13 Arts. 16 y 17 Constitutional Court Law (http://www.satv.tiesa.gov.lv/?lang=2\&mid=9). En relación con las facultades del Defensor del Pueblo de Letonia, ver: STERN, J.: "Latvia ", en KUCSKO-STADLMAYER, G. (ed.): op. cit., págs. 269 y ss.

14 Para todas las referencias a las atribuciones del Defensor del Pueblo boliviano, ver: Art. 222 de la Constitución boliviana (http://www.presidencia.gob.bo/download/constitucion.pdf) y 55 de la Ley n. ${ }^{\circ} 1836$ del Tribunal Constitucional (http://www.fiscalia.gov.bo/fiscalia/modulos/legislacion/documentos/\%5B08\%5Dley1836.pdf), que atribuye al Defensor del Pueblo la facultad de plantear acciones directas o abstractas de inconstitucionalidad, de habeas corpus, de amparo constitucional, y el recurso directo de nulidad. Sobre las facultades del Defensor del Pueblo de Bolivia para plantear recursos ante el Tribunal Constitucional del país, ver: ESPÍNOLA ORREGO, G.: "Bolivia", en ESCOBAR ROCA, G. (dir.): Defensorías del Pueblo en Iberoamérica, Aranzadi, Pamplona, 2008, págs. 68 y ss.; FERNÁNDEZ SEGADO, F.: "La justicia constitucional en Bolivia: La Ley núm. 1836, de 1 de abril de 1998, del Tribunal Constitucional", en FERNÁNDEZ SEGADO, F.: La justicia constitucional: Una visión de Derecho Comparado. Tomo III, Dyckinson, Madrid, 2009, págs. 455 y ss.

15 Para todas las referencias a las atribuciones de la Defensoría de los habitantes costaricense, ver: Arts. 73 y 75 de la Ley de la Jurisdicción Constitucional (http://www.poder-judicial.go.cr/salaconstitucional/leyes/texto\%20ley\%20jurisdiccion2.html) y art. 21 de la Ley 7319, de 17 de noviembre de 1992, de la Defensoría de los habitantes de la República (http://www.pgr.go.cr/scij/Busqueda/Normativa/Normas/nrm_repartid or.asp? param $1=\mathrm{NER} \&$ param $2=1 \&$ param $3=$ F E C H A \& param $4=$ D E S C \& param5=defensoría $\% 20$ de $\% 20$ los $\% 20$ habitantes).Sobre las facultades del Defensor de los Habitantes de Costa Rica para plantear recursos ante la Corte Suprema de Justicia del país, ver: SERRANO, C.: "Costa Rica”, en ESCOBAR ROCA, G. (dir.): op. cit., págs. 112 y ss; HERNÁNDEZ VA- 
dor $^{17}$, México $^{18}$, Guatemala ${ }^{19}$, Panamá ${ }^{20}$, Venezuela $^{21}$, Colombia $^{22}$, Nicaragua ${ }^{23}$ y Perú ${ }^{24}$, pueden acudir al Tribunal Constitucional a fin de plantear la eventual inconstitucionalidad de una ley o una norma con rango de ley.

LLE, R.: "La jurisdicción constitucional en Costa Rica", en HERNÁNDEZ VALLE, R., y PÉREZ TREMPS, P. (cood): La justicia constitucional como elemento de consolidación de la democracia en Centroamérica, Tirant, Valencia, 2000, pág. 26.

16 Para todas las referencias a las atribuciones del Defensor del Pueblo ecuatoriano, ver: Art. 215 de la Constitución Ecuatoriana, arts. 9.b) y 25.5 de la Ley Orgánica de Garantías Jurisdiccionales y Control Constitucional (http://www.tribunalconstitucional.gov.ec/index.php?option $=$ com_content\&view=article\&id=17\&Itemid=15).

17 Para todas las referencias a las atribuciones del Defensor del Pueblo salvadoreño, ver: Art. 194 de la Constitución salvadoreña, que atribuye al Procurador para la Defensa de los Derechos Humanos la facultad para promover recursos judiciales para la defensa de los derechos humanos, y arts. 2 y 41-42 de la Ley de procedimientos constitucionales (http://www.csj.gob.sv/ constitu/norm_con.htm). Sobre las facultades de la Procuraduría de los Derechos Humanos salvadoreña para plantear recursos ante la Corte Suprema de Justicia, ver: ALBINO TINETTI, J.: «La jurisdicción constitucional en El Salvador", en HERNÁNDEZ VALLE, R., y PÉREZ TREMPS, P. (cood): op. cit., págs. 78 y ss.; ANAYA BARRAZA, S. E.: "La jurisdicción constitucional en El Salvador", en GARCÍA BELAUNDE, D., y FERNÁNDEZ SEGADO, F.: La jurisdicción constitucional en Iberoamérica, Dyckinson, Madrid, 1997, págs. 607 y ss.

18 Art. 105 de la Constitución Política de los Estados Unidos mexicanos (http://www.scjn.gob.mx/RecJur/Legislacion/Documents/ConstitucionPol/1 30_27DEABRILDE2010.pdf) Sobre las facultades de la Comisión Nacional de Derechos Humanos mexicana para plantear recursos ante el Tribunal Constitucional del país, ver: SERRANO, C.: "México", en ESCOBAR ROCA, G. (dir.): op. cit., págs. 245 y ss.

19 Art. 275 de la Constitución Política de la República de Guatemala, y art. 134 de la Ley de Amparo, Exhibición Personal y de Constitucionalidad (http://www.congreso.gob.gt/ Pdf/Normativa/Amparo.PDF), que reconoce al Procurador de los Derechos Humanos la legitimación activa para interponer acciones de inconstitucionalidad contra reglamentos o disposiciones de carácter general que afecten intereses de su competencia. Sobre las facultades del Defensor del Pueblo de Guatemala para plantear recursos ante el Tribunal Constitucional del país, ver: DONAYRE PINEDO, M.: "Guatemala", en ESCOBAR ROCA, G. (dir.): op. cit., págs. 215 y ss.; FERNÁNDEZ SEGADO, F.: "La justicia constitucional en Guatemala”, en FERNÁNDEZ SEGADO, F. op. cit., págs. 295 y ss.

20 Art. 5 de la Ley n. ${ }^{\circ}$, de 5 de febrero de 1997 (http://www.defensoriadel pueblo.gob.pa/uploads/pdfs/101.pdf), en relación con el art. 2559 del Código Judicial panameño (http://www.organojudicial.gob.pa/images/normas/libro_cuarto.pdf), que legitima al Defensor del Pueblo panameño para plantear, entre otras acciones, las acciones populares. Teniendo en cuenta que la acción de inconstitucionalidad se configura en Panamá como una acción popular, que permite a toda persona impugnar ante la Corte Suprema de Justicia las leyes, los decretos de gabinete, decretos leyes, acuerdos, resoluciones y demás actos provenientes de autoridades, parece que el Defensor del Pueblo del país está facultado para plantearla. Sobre la configuración de la acción popular de inconstitucionalidad en ese país, ver: RODRÍGUEZ ROBLES, S.: "La jurisdicción constitucional en la República de Panamá (Necesidad de un Código Procesal Constitucional", en FERRER MAC-GREGOR, E. y otros (coods.): La Ciencia del Derecho Procesal Constitucional, UNAM, México, 2008, págs. 423 y ss.; RODRÍGUEZ ROBLES, F.: "La jurisdicción constitucional en Panamá", en GARCÍA BELAUNDE, D., y FERNÁNDEZ SEGADO, F.: op. cit., págs. 811 y ss.

21 Para todas las referencias a las atribuciones del Defensor del Pueblo venezolano, ver: Art. 281 de la Constitución de la República Bolivariana de Venezuela, que atribuye al Defensor del Pueblo venezolano la facultad de interponer acciones de inconstitucionalidad, amparo, habeas corpus, habeas data y las demás acciones o recursos necesarios para ejercer las funciones que le atribuye la Constitución (http://www.tsj.gov.ve/legislacion/constitucion1999.htm). 
Sin embargo, es de destacar que los Defensores del Pueblo de Colombia, El Salvador, México, Venezuela y Guatemala tienen limitada su facultad de plantear la eventual inconstitucionalidad de leyes o normas del mismo rango - según los casos- por razón de la materia, vinculándose el ejercicio de tales facultades a las funciones que el ordenamiento del país les atribuye.

En esta lógica, el Defensor del Pueblo colombiano sólo podrá plantear tales acciones respecto de "normas relacionadas con los derechos humanos" ${ }^{25}$; el Procurador para la Defensa de los Derechos Humanos salvadoreño sólo podrá hacerlo para «la protección de los derechos humanos" ${ }^{26}$; la Comisión Nacional de Derechos Humanos mexicana sólo podrá plantear una acción de inconstitucionalidad contra leyes o tratados internacionales que "vulneren los derechos humanos consagrados" en la Constitución ${ }^{27}$; el Defensor del Pueblo venezolano sólo podrá actuar en un proceso ante el Tribunal Constitucional en caso de que sea necesario para ejercer las atribuciones que le encomienda la Constitución ${ }^{28}$, básicamente, el respeto y garantía de los derechos humanos consagrados en la Constitución y los tratados internacionales ratificados por el país, y el control del correcto funcionamiento de los servicios públicos; y el Procurador de los Derechos Humanos guatemalteco sólo podrá plantear acciones de inconstitucionalidad contra leyes, reglamentos y otras disposiciones de carácter general cuando éstas «afecten intereses de su competencia" ${ }^{29}$, lo

22 Art. 9 de la Ley 24 de 1992, por la cual se establece la organización y funcionamiento de la Defensoría del Pueblo, en relación con el art. 282 de la Constitución Política de Colombia (http://www.defensoria.org.co/red/?_secc=01), que atribuye al Defensor del Pueblo del país la facultad de "demandar, impugnar o defender ante la Corte Constitucional, de oficio o a solicitud de cualquier persona y cuando fuera procedente, normas relacionadas con los derechos humanos". Sobre las facultades atribuidas al Defensor para actuar ante la Corte Constitucional: RAMÍREZ CALDERÓN, C.: "Colombia”, en ESCOBAR ROCA, G. (dir.): op. cit., págs. 87 y ss.

23 Para todas las referencias a las atribuciones del Procurador de Derechos Humanos nicaragüense, ver: Art. 21 de la Ley 212, de la Procuraduría para la defensa de los Derechos Humanos (http://www.pddh.gob.ni/docs/L212.pdf), de conformidad con los arts. 187 y ss. de la Constitución Política de la República de Nicaragua (http://www.bcn.gob.ni/banco/legislacion.html), que recoge la facultad expresa del Procurador de Derechos Humanos nicaragüense para plantear el recurso de inconstitucionalidad, amparo y exhibición personal ante la Corte Suprema de Justicia del país. Sobre las facultades atribuidas al Procurador para actuar ante la Corte: RÍOS PINEDA, R.: "Nicaragua", en ESCOBAR ROCA, G. (dir.): op. cit., págs. 298 y ss.

24 Arts. 200 y 203 de la Constitución Política del Perú y art. 99 de la Ley n. 28237 , del Código Procesal Constitucional, que atribuyen al Defensor del Pueblo peruano la facultad de plantear una acción de inconstitucionalidad contra normas con rango de ley (http://www.tc.gob.pe/constitucion.pdf). Sobre las facultades del Defensor del Pueblo peruano, ver: GARCÍA BELAUNDE, D.: "La jurisdicción constitucional en Perú", en GARCÍA BELAUNDE, D., y FERNÁNDEZ SEGADO, F.: op. cit., págs. 831 y ss.

25 Art. 9 de la Ley 24 de 1992, por la cual se establece la organización y funcionamiento de la Defensoría del Pueblo, en relación con el art. 282 de la Constitución Política de Colombia.

26 Art. 194 de la Constitución de la República de El Salvador.

27 Art. 105 de la Constitución Política de los Estados Unidos mexicanos. Sobre la interpretacion que debe darse al precepto constitucional indicado, ver: Tesis jurisprudencial 7/2007 del Pleno de la Suprema Corte de Justicia de la Nación, de 17 de abril de 2007.

28 Art. 281 de la Constitución de la República Bolivariana de Venezuela.

29 Art. 134 de la Ley de Amparo, Exhibición Personal y de Constitucionalidad. 
que parece deber interpretarse en el sentido de que sólo puede plantear una acción de inconstitucionalidad en aquellos casos en que la norma impugnada atente contra las normas que integran el catálogo nacional de derechos fundamentales ${ }^{30}$.

En la misma línea, varios Ombudsmen europeos y latinamericanos pueden interponer un recurso semejante al amparo, en el caso de que entiendan violado alguno de los derechos susceptibles de ser protegidos por esa vía procesal. En Europa del Este, los Ombudsmen húngaro, polaco y esloveno ${ }^{31}$ pueden hacer uso de ese recurso, mientras que en Latinoamérica numerosas Defensorías pueden plantear recursos semejantes al amparo español (Bolivia, Costa Rica, Ecuador, Guatemala ${ }^{32}$, Nicaragua, Colombia ${ }^{33}$, El Salvador, Panamá $^{34}$, Paraguay ${ }^{35}$, Perú ${ }^{36}$, Venezuela), o pueden interponer recursos específicos cuyo objeto es proteger alguno de los derechos reconocidos en la Constitución nacional, como el recurso de habeas corpus (Costa Rica, Bolivia, Ecuador,

30 En este sentido: GARCÍA LAGUARDIA, J. M.: "La jurisdicción constitucional en Guatemala", en HERNÁNDEZ VALLE, R., y PÉREZ TREMPS, P. (cood): op. cit., págs. 136 y ss.

31 Arts. 50 y 52 Constitucional Court Act (http://www.us-rs.si/en/about-the-court/legal-basis/constitutional-court-act/iv-review-of-the-constitutionality-and-legality-of/?lang=1).

32 Para las facultades del Defensor del Pueblo de Guatemala de plantear recursos de amparo y de exhibición personal, ver: Art. 275 de la Constitución Política de la República de Guatemala; arts. 25 y 63 de la Ley de Amparo, Exhibición Personal y Constitucionalidad, que atribuyen al Procurador de los Derechos Humanos la legitimación activa para "interponer amparo a efecto de proteger los intereses que les han sido encomendados"; y art. 85 de la Ley de Amparo, Exhibición Personal y Constitucionalidad, que atribuye a cualquier persona la legitimación activa para solicitar la exhibición personal de quien se encuentre ilegalmente privado de libertad (http://www.congreso.gob.gt/Pdf/Normativa/Amparo.PDF)

33 Arts. 10, 31, 33 y 46 y ss. del Decreto 2591 de 1991 "por el cual se reglamenta la acción de tutela consagrada en el artículo 86 de la Constitución Política" (http://www.corteconstitucional.gov.co/lacorte/DECRETO\%202591.php), en relación con el art. 282 de la Constitución Política de Colombia, que permite al Defensor del Pueblo interponer una acción de tutela para la defensa de sus derechos constitucionales fundamentales, así como solicitar a la Corte Constitucional que revise los fallos de tutela en materia de derechos fundamentales dictados por tribunales inferiores.

34 Art. 5 de la Ley n. ${ }^{\circ} 7$, de 5 de febrero de 1997 (http://www.defensoria delpueblo.gob.pa/uploads/pdfs/101.pdf), en relación con el art. 2615 del Código Judicial panameño (http://www.organojudicial.gob.pa/images/normas/libro_cuarto.pdf), que legitima al Defensor del Pueblo panameño para plantear, entre otras acciones, el recurso de amparo de garantías constitucionales.

35 Para las facultades del Defensor del Pueblo paraguayo de plantear recursos de amparo y habeas corpus, ver: Art. 10 de la Ley 631/1995, de 14 de noviembre, Orgánica de la Defensoría del Pueblo, que legitima al Defensor del Pueblo paraguayo para interponer los recursos de habeas corpus y amparo (http://www.defensoriadelpueblo.gov.py/menu/leyes.html).

36 Para las facultades del Defensor del Pueblo de Perú de plantear demandas de amparo, habeas corpus y habeas data, ver: Art. 40 de la Ley n. ${ }^{\circ}$ 28237, del Código Procesal Constitucional (http://www.tc.gob.pe/Codigo_Procesal.pdf), en línea con el art. 9 de la Ley n. ${ }^{\circ}$ 26520, Orgánica de la Defensoría del Pueblo (http://www.defensoria.gob.pe/pdf/Ley-Organica.pdf).

37 Art. 24 de la Ley 24 de 1992, por la cual se establece la organización y funcionamiento de la Defensoría del Pueblo, en relación con el art. 282 de la Constitución Política de Colombia (http://www.defensoria.org.co/red/?_secc=01), que atribuye al Defensor del Pueblo del país la facultad de "invocar el derecho de habeas corpus e interponer las acciones de tutela". 
El Salvador, Perú, Venezuela, Colombia ${ }^{37}$, Paraguay), de exhibición personal (Guatemala, Nicaragua), o el recurso de habeas data (Ecuador, Perú, Venezuela).

Aunque la articulación de estas vías procesales en cada uno de estos países es muy diferente, hay que señalar que, en la mayoría de los casos, los ordenamientos de estos países legitiman al Defensor del Pueblo para plantear la acción ante los tribunales ordinarios, siempre que éstos deban entender de la posible vulneración de los derechos concernidos bien antes de acudir ante la Corte Constitucional o como única posibilidad de recurso (Guatemala, Bolivia, Ecuador, Colombia, Panamá, Paraguay, Perú, Venezuela); y a recurrir ante el Tribunal Constitucional o la Sala Constitucional de la Corte Suprema correspondiente en el caso de que esa vía de recurso esté prevista en el ordenamiento nacional (Guatemala, Costa Rica, Ecuador, Colombia).

Más allá de las facultades reseñadas, que podrían equipararse a las atribuidas al Defensor del Pueblo español, hay que reseñar que varias de las Defensorías indicadas tiene facultades amplísimas para activar un proceso ante el Tribunal Constitucional respectivo. Sin ánimos de realizar un estudio exhaustivo, un ejemplo significativo de la amplitud de facultades de acción ante la Corte Constitucional que se atribuye a alguno de los Ombudsmen indicados lo encontramos en Estonia, país en el que el artículo 139 de la Constitución crea una institución que no sólo está encargada de garantizar los derechos de los ciudadanos, sino también de ejercer como una suerte de guardián de la Constitución. Las atribuciones del Õiguskantsler exceden, por indicación expresa de la Constitución nacional, de la defensa de los derechos de los ciudadanos, en la medida en que la Constitución estonia lo caracteriza como una autoridad independiente, que debe revisar la adecuación a la Constitución y las leyes de las normas adoptadas por el poder ejecutivo, el legislativo y los entes locales, pudiendo plantear ante la Corte Suprema de su país la inconstitucionalidad de cualquier norma de alcance general.

Esta rápida revisión de algunos ordenamientos cercanos al nuestro nos permite concluir que la facultad del Defensor del Pueblo español de plantear recursos de amparo y de inconstitucionalidad ante el Tribunal Constitucional no es tan atípica como se había apuntado. Sin embargo, esta primera conclusión debe ser matizada, en la medida en que los sistemas de justicia constitucional a los que se ha hecho referencia y la propia configuración de la institución del Defensor del Pueblo en cada uno de estos países presenta notables divergencias. En esta lógica, no se podrán valorar de idéntico modo las facultades que se han atribuido al Ombudsman de Estonia, configurado como guardián de la Constitución, que las facultades atribuidas a otros Defensores del Pueblo, caracterizados como órganos de garantía de los derechos fundamentales. Tampoco podrá valorarse de idéntico modo la atribución al Ombudsman nacional de legitimación para activar el control abstracto de constitucionalidad de leyes o normas con rango de ley cuando esa legitimación se reconoce también a cualquier persona o cualquier ciudadano, como ocurre en el caso de Hungría, Panamá, o Guatemala, que cuando esa legiti- 
mación se atribuye sólo a determinados órganos constitucionales o partes de los mismos, configurándose un acceso relativamente restringido al Tribunal Constitucional respectivo, como sería el caso español.

A pesar de estas notables divergencias, el breve análisis de Derecho Comparado realizado permite perfilar algunos elementos comunes a los ordenamientos que atribuyen las facultades estudiadas a sus Ombudsmen. Destaca así que la mayoría de los países indicados son democracias más o menos recientes, en las que los sistemas de justicia constitucional tienden a mezclar elementos de los sistemas difusos y concentrados de control de constitucionalidad $^{38}$ y a ampliar notablemente los sujetos legitimados activamente para acudir al Tribunal Constitucional con el objetivo de acercar la justicia constitucional al ciudadano ${ }^{39}$. Sin embargo, parece más atípico configurar un sistema de justicia constitucional en el que el acceso al Tribunal Constitucional, al menos para activar el control abstracto de constitucionalidad de las leyes, es relativamente estricto y, paralelamente, reconocer legitimación para activar ese control al Ombudsman respectivo.

En la misma línea, en la mayoría de los países analizados, el Ombudsman se ha configurado expresamente como órgano de garantía de los derechos fundamentales, y no sólo como órgano de control de la Administración Pública ${ }^{40}$, distanciándose así de la función originaria que se atribuía a estas instituciones en los ordenamientos nórdicos ${ }^{41}$. Parece así haber prevalecido la idea de que la atribución al Ombudsman respectivo de ciertas facultades de acción ante la jurisdicción constitucional u ordinaria sería necesaria para que la institución pudiera convertirse en un garante de los derechos fundamentales eficaz ${ }^{42}$.

38 En este sentido, en relación con los países de Europa del Este: MISTÒ, M.: "La giustizia costituzionale nei Paesi dell'Europa centro-orientale", en OLIVETTI, M. y GROPPI, T.: op. cit., págs. 289 y ss. En relación con los países latinoamericanos: BREWER-CARIAS, A. R.: "La jurisdicción constitucional en América Latina", en GARCÍA BELAUNDE, D., y FERNÁNDEZ SEGADO, F.: op. cit., págs. 126 y ss.; LÖSING, N.: La jurisdiccionalidad constitucional en Latinoamérica, Dyckinson, Madrid, 2002, especialmente, págs. 342 y ss.

39 En este sentido, en relación con los países de Europa del Este: MISTÒ, M.: op. cit., págs. 319 y ss. En relación con los países latinoamericanos: GROPPI, T.: "Titularidad y legitimación ante la jurisdicción constitucional. Una perspectiva comparada", en FERRER MAC-GREGOR, E. y otros (coods.): op. cit., págs. 250 y ss.; BREWER-CARIAS, A. R.: op. cit., págs. 148 y ss.

40 En este sentido, en relación con las Defensorías europeas: KUCSKO-STADLMAYER, G. (ed.): op. cit., especialmente, pág. 503. En relación con las Defensorías latinoamericanas: ESCOBAR ROCA, G. (dir.): op. cit.

41 En relación con la función principal que se ha atribuido históricamente al Ombudsman: CARBALLO ARMAS, P.: op. cit., págs. 28 y ss. y 49 y ss.; GIL ROBLES y GIL DELGADO, A.: $E l$ control parlamentario de la Administración (El Ombudsman), INAP, Madrid, 1981, especialmente, págs. 37 y ss., 249 y ss. y 317 y ss.; FAIRÉN GUILLÉN, V.: op. cit., págs. 38 y ss. y 265 y ss.; PÉREZ-UGENA y COROMINA, M.: Defensor del Pueblo y Cortes Generales, Congreso de los Diputados, Madrid, 1996, págs. 59 y ss. y 65 y ss.

42 El vínculo entre el ejercicio de la función de garantía de los derechos fundamentales y las facultades de acción ante la justicia constitucional también se apunta en: KUCSKO-STADLMAYER, G.: "The Legal Structures of Ombudsman-Institutions in Europe-Legal Comparative Analysis", en KUCSKO-STADLMAYER, G. (ed.): op. cit., págs. 51-52. 
Analizadas las características que presenta la cuestión estudiada en otros países, veamos lo que ocurre en el nuestro.

\section{LA LEGITIMACIÓN ACTIVA DEL DEFENSOR DEL PUEBLO PARA PLANTEAR EL RECURSO DE INCONSTITUCIONALIDAD ANTE EL TRIBUNAL CONSTITUCIONAL: EL EXCESO COMPETENCIAL}

El artículo 162.1.a) de la Constitución española enuncia los sujetos legitimados para interponer el recurso de inconstitucionalidad ante el Tribunal Constitucional, incluyendo al Defensor del Pueblo entre ellos. La legitimación del Defensor del Pueblo, reiterada en los artículos 29 de la Ley Orgánica 3/1981, de 6 de abril, del Defensor del Pueblo (LODP, en adelante), y 32.1.b) de la Ley Orgánica 2/1979, de 3 de octubre, del Tribunal Constitucional (LOTC, en adelante), permite al Defensor del Pueblo plantear la eventual inconstitucionalidad de cualquier ley o norma con rango de ley ante el Tribunal Constitucional, ubicando a este órgano en una posición un tanto extraordinaria en relación con su Comisionado, las Cortes Generales, máxime si se tiene en cuenta que la legitimación para interponer el recurso de inconstitucionalidad en nuestro país se limita, con la única excepción del Defensor del Pueblo, a sujetos públicos con una clara componente política ${ }^{43}$.

La posición del Defensor del Pueblo resulta todavía más paradójica si se analiza el iter que llevó a las Cortes Constituyentes españolas a atribuirle esta facultad, la configuración de la misma que ha realizado el ordenamiento español y el uso que de la misma han hecho los distintos titulares de la institución, en la medida en que el análisis conjunto de estos elementos no parece justificar la atribución al Defensor del Pueblo de una facultad concebida en términos tan excesivamente amplios.

\section{III.1. LA LEGITIMACIÓN ACTIVA PARA INTERPONER RECURSOS DE INCONSTITUCIONALIDAD EN EL DEBATE CONSTITUYENTE Y EN EL PROCESO DE ELABORACIÓN DE LA LOTC Y LA LODP}

A pesar de la indiscutible relevancia que tiene la legitimación activa del Defensor del Pueblo para plantear recursos de inconstitucionalidad ante el Tribunal Constitucional, llama la atención que la facultad reseñada apenas fuera objeto de discusión en el debate constituyente, deliberándose escasamente sobre el alcance y el porqué de esa legitimación. La mayoría de los Grupos Parlamentarios parecían apoyar la atribución al Defensor del Pueblo de esta fa-

43 Así parece indicarlo el propio Tribunal Constitucional, que en la STC 5/1981 (FJ 3) vincula la legitimación activa para interponer le recurso de inconstitucionalidad con la "alta cualificación política" de los órganos legitimados para plantearlo. En este sentido, también: TORRES MURO, I.: La legitimación en los procesos constitucionales, Reus, Madrid, 2007, págs. 33 y ss. 
cultad, con la clara excepción del Grupo de UCD, que fue el único que planteó una enmienda dirigida a eliminar la facultad que el Anteproyecto de Constitución ya reconocía al Defensor del Pueblo.

Efectivamente, el artículo 153.1.a) del Anteproyecto de Constitución ${ }^{44}$, resultado de los trabajos de la Ponencia creada en el seno de la Comisión Constitucional del Congreso, reconocía al Defensor del Pueblo legitimación para interponer el recurso de inconstitucionalidad, atribuyendo esta facultad también a los Presidentes de Congreso y Senado, al Presidente del Gobierno, a los Presidentes de las Asambleas de los "territorios autónomos", a los Presidentes de los Consejos de Gobierno de esos mismos territorios, a 50 Diputados y a 25 Senadores.

Este precepto fue objeto de ocho enmiendas en el seno del Congreso de los Diputados ${ }^{45}$, alguna de las cuales proponían la extensión de la legitimación activa para plantear el recurso de inconstitucionalidad, bien atribuyendo tal facultad a eventuales Defensores del Pueblo autonómicos - y no sólo al Defensor del Pueblo estatal- ${ }^{46}$, bien atribuyendo tal facultad a un determinado número de ciudadanos o electores ${ }^{47}$, pretendiéndose así la introducción de una suerte de acción popular de inconstitucionalidad que exigiera el apoyo de un número razonable de ciudadanos.

Sin embargo, desde el punto de vista de la institución que ahora estudiamos, la enmienda más relevante fue, sin duda, la enmienda núm. 77948, presentada por UCD, y que proponía la supresión de la mención al Defensor del Pueblo como órgano legitimado para interponer el recurso de inconstitucionalidad y el recurso de amparo. La enmienda presentada por UCD se vinculaba claramente con una determinada visión de la nueva institución que la Constitución estaba configurando, en la medida en que el mismo Grupo Parlamentario presentaba también una enmienda al artículo $46^{49}$, en el que se regulaba la institución del Defensor del Pueblo en el Anteproyecto de Constitución, incidiendo en la configuración de la nueva institución como un

44 Anteproyecto de Constitución, Boletín Oficial de las Cortes Generales, de 5 de enero de 1978, núm. 44, pág. 696.

45 Constitución española, Trabajos Parlamentarios, Cortes Generales, 1980, pág. 116.

46 Enmienda núm. 64, presentada por el Sr. Letamendia Belzunce (Grupo Parlamentario Mixto), Constitución española, Trabajos Parlamentarios, Cortes Generales, 1980, pág. 116.

47 Enmienda núm. 35, presentada por el Sr. De la Fuente de la Fuente (Grupo Parlamentario de Alianza Popular), en la que se proponía la extensión de la legitimación para interponer el recurso de inconstitucionalidad a 10.000 ciudadanos, Constitución española, Trabajos Parlamentarios, Cortes Generales, 1980, pág. 116; Enmienda núm. 579, del Grupo Parlamentario Mixto, en la que se proponía la extensión de la legitimación para interponer el recurso de inconstitucionalidad a 200.000 electores, Constitución española, Trabajos Parlamentarios, Cortes Generales, 1980, pág. 356.

48 Enmienda núm. 779, presentada por el Grupo Parlamentario de Unión de Centro Democrático, Constitución española, Trabajos Parlamentarios, Cortes Generales, 1980, pág. 500. Se recomienda ver el análisis de la enmienda de UCD realizado por: GIL — ROBLES, A.: El defensor del pueblo (Comentarios en torno a una proposición de Ley orgánica), Civitas, Madrid, 1979, págs. 39 y ss.

49 Idem supra. 
órgano de defensa de los derechos de los ciudadanos cuya actividad debía alejarse del ámbito jurisdiccional y del ejercicio de acciones frente a los tribunales, y centrarse exclusivamente en el control de la actividad administrativa.

La enmienda presentada por UCD, que no sería objeto de debate parlamentario, planteaba una cuestión de profunda relevancia, en cuanto trataba de perfilar con mayor claridad los contornos de la institución. En este sentido, llamaba poderosamente la atención que el artículo 46 del Anteproyecto de Constitución se limitara a definir al Defensor del Pueblo como el Alto Comisionado de las Cortes para la defensa de los derechos comprendidos en el Título I, indicando que para desarrollar la tarea indicada el Defensor podría plantear el recurso preferente y sumario ante los tribunales ordinarios y el recurso de amparo ante el Tribunal Constitucional ${ }^{50}$.

Nada se señalaba, sin embargo, en relación con la facultad de control de la Administración que tradicionalmente ejercen los Ombudsmen ${ }^{51}$. A fin de suplir esa carencia, alguna de las enmiendas ${ }^{52}$ presentadas en el Congreso en torno al artículo 46 del Anteproyecto propugnaron la ampliación de las competencias de la institución recién creada al atribuirle la función de supervisar la actividad de la Administración e informar de ello a las Cortes Generales ${ }^{33}$. Estas enmiendas, que introducían al Defensor del Pueblo en la lógica de los Ombudsmen tradicionales, fueron aceptadas desde el Informe de la Ponencia designada en el seno de la Comisión de Asuntos Constitucionales y Libertades Públicas del Congreso de los Diputados ${ }^{54}$, sin que se produjera debate alguno al respecto en el seno del Congreso ${ }^{55}$ y sin que se estableciera vínculo alguno entre las nuevas competencias que se atribuían al Defensor y su facultad de interponer el recurso de inconstitucionalidad y de amparo ante el Tribunal Constitucional.

De hecho, la atribución de legitimación activa al Defensor del Pueblo para plantear recursos de inconstitucionalidad parecía tener una lógica que

50 Anteproyecto de Constitución, Boletín Oficial de las Cortes Generales, de 5 de enero de 1978, núm. 44, pág. 676: “Una Ley Orgánica regulará la institución del Defensor del Pueblo, como alto comisionado de las Cortes Generales para la defensa de los derechos comprendidos en este Título, quien, en todo caso, podrá ejercer las acciones a que se refiere el apartado dos del artículo anterior (esto es, los recursos de amparo ordinario y constitucional)".

51 Ha llamado la atención sobre este punto, extraño si se tienen en cuenta las facultades tradicionales de los Ombudsmen, GIL-ROBLES, A.: op. cit., 1979, pág. 29.

52 En relación con ese precepto se presentaron un total de ocho enmiendas: Constitución española, Trabajos Parlamentarios, Cortes Generales, 1980, pág. 85.

53 En este sentido, las enmiendas núm. 391 y 697, presentadas respectivamente por el Grupo Parlamentario Socialista del Congreso y el Grupo Parlamentario Comunista, Constitución española, Trabajos Parlamentarios, Cortes Generales, 1980, págs. 85 y ss.

54 Anteproyecto de Constitución, Informe de la Ponencia, Boletín Oficial de las Cortes Generales, de 17 de abril de 1978, núm. 82, págs. 1550 y 1151.

55 La total ausencia de debate se observa en el Diario de Sesiones del Congreso de los Diputados, Comisión de Asuntos Constitucionales y Libertades Públicas, de 23 de mayo de 1978, núm. 72, pág. 2627, en el que se recoge únicamente la votación del texto de la ponencia, que se aprueba por 30 votos a favor y uno en contra. 
nada tenía que ver con las funciones originales y principales de la institución, véase la defensa de los derechos del Título I de la Constitución, tal y como se deducía del debate que tuvo lugar en la Comisión de Asuntos Constitucionales y Libertades Públicas del Congreso ${ }^{56}$ en torno al entonces artículo 155 del proyecto. En relación con ese precepto, en el que se recogían los órganos legitimados para interponer los recursos de inconstitucionalidad y amparo, la Comisión debatió varias enmiendas, entre ellas, la enmienda presentada por el Sr. Licino de la Fuente (Grupo de Alianza Popular), que propugnaba la extensión de la legitimación activa para interponer el recurso de inconstitucionalidad a 10.000 ciudadanos o a un número suficientemente significativo de ciudadanos, justificando su posición en que todos los órganos legitimados para interponer el recurso contemplados en el texto del proyecto tenían una notable componente política —inclusive el Defensor del Pueblo-, de modo que podrían no estar interesados en plantear la eventual inconstitucionalidad de una ley o una norma con rango de ley que, en cierto modo, habrían contribuido a legitimar. En esa lógica, entendía el Sr. De la Fuente, debía reconocerse tal facultad a un número significativo de ciudadanos de modo que se garantizara un acceso directo de la ciudadanía al Tribunal Constitucional a la par que se evitaba la proliferación innecesaria de recursos ante el Alto Tribunal a la que podría dar lugar el reconocimiento de una acción individual con ese objeto.

La enmienda planteada por el Sr. De la Fuente fue rechazada por el resto de Grupos Parlamentarios ${ }^{57}$. Sin embargo, parece llamativo que uno de los argumentos que se utilizaron para rechazar la propuesta del Sr. De la Fuente, considerada inconveniente en el marco del sistema de justicia constitucional que se estaba configurando, fue precisamente que el Defensor del Pueblo podría canalizar las inquietudes de la población en lo que se refería al planteamiento del recurso de inconstitucionalidad ${ }^{58}$. La legitimación activa del Defensor del Pueblo para interponer el recurso de inconstitucionalidad no se vinculaba, por tanto, a la función constitucional que se atribuía a ese órgano, sino más bien a una voluntad aperturista del sistema de justicia constitucional que se estaba configurando, que limitaba la posibilidad de plantear la inconstitucionalidad de leyes y normas con rango de ley por vía de acción a sujetos institucionales con una componente claramente política, y pretendía paralelamente realizar un guiño a la ciudadanía, atribuyendo a uno de los órganos llamados a defender sus derechos, la facultad de plantear esa inconstitucionalidad ${ }^{59}$.

56 Diario de Sesiones del Congreso, de 19 de junio de 1978, núm. 92, págs. 3447 y ss.

57 Fue rechazada por 28 votos en contra y dos a favor: Diario de Sesiones del Congreso de los Diputados, de 19 de junio de 1978, núm. 92, pág. 3451.

58 En este sentido se manifestaba el Sr. Solé Tura (Grupo Parlamentario Comunista), Diario de Sesiones del Congreso, de 19 de junio de 1978, núm. 92, págs. 3448 y ss.

59 Esa voluntad aperturista ha sido subrayada por alguno de los miembros de la Ponencia que elaboró el Anteproyecto de Constitución: PECES-BARBA, G.: intervención en el marco de la III Ponencia "Intervención del Defensor del Pueblo en procedimientos jurisdiccionales", en las Jor- 
El debate del proyecto constitucional en el Senado tampoco dio excesivos frutos en lo que se refiere a la clarificación de la facultad de interponer recursos de inconstitucionalidad que se atribuía al Defensor del Pueblo. Ninguna de las enmiendas ${ }^{60}$ que se presentaron al entonces artículo 156 del proyecto tuvo como finalidad retocar la facultad atribuida al Defensor del Pueblo. Sin embargo, en el debate de varias de las enmiendas ${ }^{61}$ que se presentaron al artículo 49 del texto, en el que se regulaba la figura del Defensor del Pueblo, surgieron argumentos llamativos que mostraban las reticencias de una parte importante de Senadores a atribuir facultades de acción en vía jurisdiccional al Defensor del Pueblo ${ }^{62}$. En este sentido, los posicionamientos más claros se plasmaron en las intervenciones de los Srs. Pedrol Rius (Grupo Mixto), Martín-Retortillo Baquer (Grupo de Progresistas y Socialistas Independientes), y Ollero Gómez (Grupo Agrupación Independiente) ${ }^{63}$, que subrayaron el carácter "híbrido" " ${ }^{64}$ de la institución, tal y como quedaba configurada en el texto del proyecto, y señalaron que el Defensor del Pueblo debería centrar sus funciones en el control de la actividad administrativa, configurándose como una magistratura de opinión, y dejando la intervención en vía jurisdiccional para el Ministerio Fiscal y los propios ciudadanos, que contaban con diversos instrumentos para hacer valer sus derechos frente a los tribunales. Llama la atención que el Senador Ollero Gómez ${ }^{65}$ criticara la configuración de la institución como una suerte de garante o guardián de la Constitución, que sería innecesario, en cuanto esa función ya era desempeñada por otras instituciones del Estado.

A pesar del intenso debate en torno a la propia configuración de los perfiles de la institución, los partidos mayoritarios - UCD y Socialistas- mostraron pronto su conformidad — en el caso de UCD, de forma poco entusias-

nadas Diez años de la Ley Orgánica del Defensor del Pueblo. Problemas y Perspectivas. Universidad Carlos III de Madrid, Madrid, 1992, págs. 211 y ss, en la que se señala que los constituyentes atribuyeron esa facultad al Defensor del Pueblo para que la interposición del recurso de inconstitucionalidad "no fuera cosa solamente de iniciados" y se abriera "una vía distinta y más amplia" que la ofrecida por los otros órganos a los que se atribuye esa facultad.

60 Tan sólo se presentaron siete enmiendas al art. 156 del texto del Proyecto de Constitución aprobado por el Pleno del Congreso de los Diputados, Constitución española, Trabajos Parlamentarios, Cortes Generales, 1980, pág. 2659.

61 Se presentaron once enmiendas al art. 49 del texto del Proyecto de Constitución aprobado por el Pleno del Congreso de los Diputados, Constitución española, Trabajos Parlamentarios, Cortes Generales, 1980, pág. 2631.

62 El debate al respecto puede verse en el Diario del Sesiones del Senado, de 31 de agosto de 1978, núm. 47, págs. 2127 y ss.

63 Una reflexión sobre las intervenciones indicadas, puede encontrarse en: LUNA ABELLA, C.: "Artículo 29", en ROVIRA VIÑA, A. (dir): Comentarios a la Ley Orgánica del Defensor del Pueblo, Aranzadi, Navarra, 2002, págs. 720 y ss.

64 Expresión utilizado por el Sr. Martín-Retortillo Baquer (Grupo Parlamentario Progresistas y Socialistas Independiente), Diario del Sesiones del Senado, de 31 de agosto de 1978, núm. 47, pág. 2129.

65 Intervención del Sr. Ollero Gómez (Grupo Parlamentario Agrupación Independiente), Diario del Sesiones del Senado, de 31 de agosto de 1978, núm. 47, pág. 2129. 
ta ${ }^{66}$ - con el texto del proyecto y con la atribución de las facultades reseñadas al Defensor del Pueblo, de modo que ambos artículos fueron aprobados en el Senado sin cambios significativos en lo que a la institución del Defensor se refería. Y de hecho, así permanecería también en la última versión del texto constitucional $^{67}$, elaborado por la Comisión Mixta Congreso-Senado, que se limitaría a refundir los dos incisos del actual artículo $54 \mathrm{CE}$ en un solo inciso, en el que se señala que el Defensor del Pueblo es designado por las Cortes Generales para la defensa de los derechos del Título I CE, "a cuyo efecto podrá supervisar la actividad de la Administración, dando cuenta a las Cortes Generales".

La institución así configurada en sede constitucional, muy a pesar de las enmiendas y opiniones plasmadas por varios Grupos Parlamentarios, tanto en el Congreso como en el Senado ${ }^{68}$, no puede considerarse una mera magistratura de opinión, llamada a dedicarse exclusivamente al control del actuar administrativo. Por el contrario, nuestros constituyentes parecían tener en mente - $\mathrm{O}$, al menos, una parte de ellos así lo hacía - una institución un tanto distinta, creada con el objetivo principal de defender los derechos reconocidos por la Constitución a los ciudadanos e investida de ciertas facultades que iban más allá del mero control administrativo e implicaban su intervención en sede jurisdiccional, aunque no necesariamente en defensa de los derechos del Título I de la Constitución.

Las inconsistencias en la configuración inicial de la institución se obviaron por completo durante la tramitación parlamentaria del Proyecto de Ley Orgánica del Tribunal Constitucional ${ }^{69}$. Sin embargo, afloraron nuevamente durante la tramitación de la proposición de Ley Orgánica del Defensor del Pueblo, presentada por el Grupo Parlamentario Socialista del Con-

66 Este posicionamiento poco entusiasta se debe a la posición mantenida por el Grupo Parlamentario en el Congreso de los Diputados. En este sentido, LUNA ABELLA ha subrayado la diferencia que se observa en el comportamiento de UCD en el Congreso y en el Senado en relación con la configuración de la figura del Defensor del Pueblo. Si bien en el Congreso, UCD fue la única agrupación que planteó de forma seria la necesidad de configurar al Defensor del Pueblo como una magistratura de opinión, sin facultades para iniciar acciones jurisdiccionales, en el Senado su posición cambió, pasando a defender los perfiles generales de la institución tal y como ésta había sido configurada en el Congreso, y tratando, al menos, de dotar al Ministerio Fiscal, llamado a ejercer la acción jurisdiccional en defensa de los derechos y la legalidad, de las mismas atribuciones que al propio Defensor del Pueblo. En este sentido: LUNA ABELLA, C.: op. cit., págs. 722 y ss.

67 Dictamen de la Comisión Mixta Congreso-Senado sobre el Proyecto de Constitución, Boletín Oficial de las Cortes Generales, de 28 de octubre de 1978, núm. 170, págs. 3701 y ss.

68 En este sentido, LUNA ABELLA, C.: op. cit., págs. 719 y ss., señala como se enfrentaron en el proceso constituyente dos concepciones muy distintas de cómo debía configurarse la institución del Defensor del Pueblo y qué poderes deberían serle atribuidos.

69 En este sentido, destaca que ninguna de las enmiendas presentadas en el Congreso de los Diputados y el Senado en torno a los arts. 35 y 50 del Proyecto (arts. 32 y 46 del texto remitido por el Congreso al Senado) se rifiera a las facultades del Defensor del Pueblo de interponer el recurso de amparo o de inconstitucionalidad. Ver: Tribunal Constitucional, Trabajos Parlamentarios, Cortes Generales, 1980. 
greso $^{70}$. La proposición de ley contenía un artículo 19 en el que se señalaba escuetamente que el Defensor del Pueblo estaba legitimado para interponer los recursos de amparo e inconstitucionalidad, "de acuerdo con lo dispuesto en la Constitución y en la Ley Orgánica del Tribunal Constitucional». El precepto indicado no fue objeto de enmienda alguna en el Congreso, aunque sí se planteó una enmienda en el Senado, presentada por el Sr. Bosque Hita (Grpo Mixto), en la que se pretendía que el Defensor del Pueblo pudiera presentar el recurso de inconstitucionalidad y el de amparo en cualquier momento, sin necesidad de respetar el plazo general aplicable al resto de sujetos legitimados para interponerlos ${ }^{71}$. La enmienda indicada fue rechazada sin debate público alguno ${ }^{72}$, quedando el texto original del proyecto con su redacción inicial, aunque con un cambio sustancial en la numeración, ya que pasó a convertirse en el artículo 29 LODP.

A pesar de esta ausencia de enmiendas, que se explica sin duda por la imperatividad del texto constitucional, las reflexiones de los parlamentarios sobre la atribución al Defensor del Pueblo de la facultad de interponer recursos de inconstitucionalidad se plasmaron en diversos debates que tuvieron lugar en el Pleno del Congreso y del Senado. La lectura de los mismos aporta una idea poco clara de la institución que los parlamentarios tenían en mente en el momento de redactar la LODP. Varias intervenciones señalaron la voluntad de seguir la senda marcada por la institución del Ombudsman, configurando al Defensor del Pueblo como una magistratura de opinión, alejada de la lucha partidista, dotada de la máxima auctoritas y llamada a controlar la Administración en defensa de los derechos de los ciudadanos ${ }^{73}$. Sin embargo, otras intervenciones subrayaron la complejidad de una institución a la que no sólo se atribuían funciones de control del actuar administrativo, sino también ciertas facultades que le permitían acudir al Tribunal Constitucional en vía de amparo o de inconstitucionalidad ${ }^{74}$. Algunos parlamentarios parecían justificar esas facultades al vincularlas con la función principal que se atribuía al Defensor, esto es, la defensa de los derechos de los ciudadanos ${ }^{75}$. Sin embargo, otros

70 Proposición de Ley Orgánica del Defensor del Pueblo, presentada por el Grupo Parlamentario Socialista del Congreso, Boletín Oficial de las Cortes Generales, Congreso de los Diputados, de 20 de junio de 1979, núm. 39-I, serie B.

71 Enmienda núm. 4, presentada por el Sr. Vicente Bosque Hita, Ley Orgánica del Defensor del Pueblo, Trabajos Parlamentarios, Cortes Generales, 1981, pág. 154.

72 No llegó a ser objeto de debate en el Pleno del Senado (Diario de Sesiones del Senado, de 18 de febrero de 1981, núm. 94, pág. 4881 —en ese momento el precepto en el que se recogía la legitimación del Defensor ante el Tribunal Constitucional era el art. 33 del Proyecto), pero no se conoce lo que ocurrió en Comisión, ya que esos debates no se han hecho públicos.

73 Intervención del Sr. Ojeda Escobar (Grupo Socialista Andaluz) en el Pleno del Senado, Diario de Sesiones del Senado, de 17 de febrero de 1981, núm. 93, págs. 4844 y ss.

74 Intervención del Sr. Alzaga Villaamil (Grupo Parlamentario Centrista) en el Pleno del Congreso, Diario de Sesiones del Congreso, de 11 de noviembre de 1980, núm. 127, págs. 7961 y ss.

75 Intervención del Sr. Peces-Barba Martínez (Grupo Parlamentario Socialista del Congreso) en el Pleno del Congreso, Diario de Sesiones del Congreso, de 11 de noviembre de 1980, núm. 127, págs. 7957 y ss.; Intervención del Sr. Villar Arregui (UCD) en el Pleno del Senado, Diario de Sesiones del Senado, de 17 de febrero de 1981, núm. 93, págs. 4841 y ss. 
parlamentarios iban más allá, subrayando que el Defensor del Pueblo podía ser caracterizado como un "Defensor de la Constitución", en la medida en que podía interponer recursos de inconstitucionalidad contra cualquier ley ${ }^{76}$.

Parece claro pues que las Cortes que llevaron a cabo la tarea de desarrollar legislativamente la figura del Defensor del Pueblo no pudieron erradicar las contradicciones que surgieron en torno a la institución en el debate constituyente: el Defensor del Pueblo se configuró así como una institución de garantía de los derechos constitucionales, a la que paralelamente se reconocieron facultades para controlar el actuar administrativo y para plantear ciertos recursos ante el Tribunal Constitucional. Sin embargo, no quedaba claro del todo por qué a una institución pensada para garantizar el respeto de los derechos reconocidos constitucionalmente se le reconocía la facultad de interponer el recurso de inconstitucionalidad contra cualquier ley o norma con rango de ley ${ }^{77}$.

Si nuestros constituyentes querían convertir al Defensor del Pueblo en una suerte de "Defensor de la Constitución", en línea con la idea ya propuesta por Kelsen ${ }^{78}$ y tal y como ha apuntado parte de la doctrina española ${ }^{79}$, hubiera parecido conveniente una configuración expresa de la institución como garante de la Constitución, ya que la versión actual no parece dejar clara la diferencia, en ese sentido, entre el Defensor del Pueblo y el resto de los órganos legitimados para interponer el recurso de inconstitucionalidad, que podrían también calificarse de "Defensores de la Constitución". Además, el propio Kelsen señalaba que, en el caso de optarse por configurar una órgano encargado de la defensa de la Constitución y de plantear cualquier acción al respecto al Tribunal Constitucional, éste debería contar con garantías suficientes de independencia tanto frente al legislativo como frente al ejecutivo; garantías que podría quizás no cumplir una institución definida como "Alto Comisionado de las Cortes".

Si la pretensión de nuestros constituyentes era abrir un cauce indirecto para que la ciudadanía pudiera plantear la eventual inconstitucionalidad de una ley o una norma con rango de ley, dada la falta de reconocimiento de tal posibilidad a un ciudadano o un grupo de ciudadanos, tal y como se apuntó en los debates constituyentes y como ha señalado la doctrina ${ }^{80}$, parece que la

76 Intervenciones del Sr. Calatayud Maldonado (UCD) en el Pleno del Senado, Diario de Sesiones del Senado, de 17 de febrero de 1981, núm. 93, págs. 4834 y ss. y 4858 y ss.

77 Sobre el carácter poco claro de ciertos posicionamientos de los constituyentes, ver: GIL ROBLES, A.: op. cit., 1979, pág. 66.

78 En este sentido: KELSEN, H.: La garantía jurisdiccional de la Constitución (La justicia constitucional), obra recogida en Escritos sobre la democracia y el socialismo, Editorial Debate, Madrid, 1988, pág. 147.

79 En este sentido: LUNA ABELLA, C.: op. cit., págs. 743 y ss.; PÉREZ-UGENA y COROMINA, M.: op. cit., págs. 295 y ss.; CARRO FERNÁNDEZ-VALMAYOR, J. L.: intervención en el marco de la III Ponencia "Intervención del Defensor del Pueblo en procedimientos jurisdiccionales", en las Jornadas Diez años de la Ley Orgánica del Defensor del Pueblo. Problemas y Perspectivas. Universidad Carlos III de Madrid, Madrid, 1992, págs. 210 y ss.

80 En este sentido: GONZÁLEZ RIVAS, J. J.: La justicia constitucional: Derecho Comparado y español, Editoriales de Derecho Reunidas, Madrid, 1985, págs. 149 y ss.; LUNA ABELLA, C.: op. 
institución debería haberse configurado de una forma más cercana a los ciudadanos. El Defensor del Pueblo, tal y como es concebido por la Constitución, no puede verse como una suerte de representante de la ciudadanía que la sustituiría en el ejercicio de esa legitimación: el Defensor del Pueblo es elegido por las Cortes Generales y, tal y como ahora veremos, interpone el recurso de inconstitucionalidad siguiendo su propio criterio, de modo que no se aprecia en que puede contribuir su legitimación a "democratizar" el acceso a nuestro Tribunal Constitucional.

Sin embargo, un último argumento apuntado en los debates parlamentarios sobre la institución y recogido también por la doctrina española ${ }^{81}$, podría quizás fundamentar de forma más sólida la atribución de esta facultad al Defensor del Pueblo. En alguno de los debates parlamentarios reseñados parecía plantearse el vínculo existente entre la función principal de la institución, la defensa de los derechos del Título I de la Constitución, y las facultades de acción ante el Tribunal Constitucional que el texto constitucional le confería: parecía entenderse así que la defensa de tales derechos no sería eficaz sin la posibilidad de instar la inconstitucionalidad de aquellas leyes que, por su contenido, atentaran contra los derechos reconocidos constitucionalmente. Este argumento, que vincula el ejercicio de la facultad atribuida al Defensor con su función principal, podría justificar la atribución de la facultad reseñada al Defensor del Pueblo siempre que se estableciera un vínculo claro entre el ejercicio de esa facultad y la función que se atribuye a la institución, tal y como se ha hecho, por ejemplo, en Venezuela o Colombia. Sin embargo, tal y como ahora veremos con más detalle, la facultad atribuida al Defensor del Pueblo español es una facultad totalmente desligada de su función principal.

\section{III.2. LOS REQUISITOS QUE CONFIGURAN LA FACULTAD DE INTERPONER ReCursos De inconstitucionalidad por EL Defensor Del Pueblo}

Tal y como ya hemos indicado, los artículos 162.1.a) de la Constitución, 32 LOTC y 29 LODP atribuyen al Defensor del Pueblo la facultad de plantear el recurso de inconstitucionalidad. El Defensor del Pueblo podrá plantear el

\footnotetext{
cit., págs. 743 y ss.; CARBALLO ARMAS, P.: op. cit., pág. 159; VINTRÓ CASTELLS, J.: “The Ombudsman and the Parliamentary Comités on Human Rights in Spain", en HOSSAIN, K. y otros (eds.): Human Rights Commissions and Ombudsman Offices. National Experiences throughout the World, Kluwer Law International, La Haya, 2000, pág. 411; PÉREZ-UGENA y COROMINA, M.: op. cit., págs. 295 y ss.

81 En este sentido: PÉREZ-UGENA y COROMINA, M.: op. cit., págs. 291 y ss.; AGUILAR FERNÁNDEZ-HONTORIA, J.: intervención en el marco de la III Ponencia "Intervención del Defensor del Pueblo en procedimientos jurisdiccionales", en las Jornadas Diez años de la Ley Orgánica del Defensor del Pueblo. Problemas y Perspectivas. Universidad Carlos III de Madrid, Madrid, 1992, págs. 206 y ss.; PAREJO ALFONSO, L.: intervención en el marco de la III Ponencia "Intervención del Defensor del Pueblo en procedimientos jurisdiccionales", en las Jornadas Diez años de la Ley Orgánica del Defensor del Pueblo. Problemas y Perspectivas. Universidad Carlos III de Madrid, Madrid, 1992, págs. 208 y s.
} 
recurso bien de oficio o a instancia de parte ${ }^{82}$ y, según lo que prevé el artículo 18.1.b) del Reglamento de Organización y Funcionamiento del Defensor del Pueblo, la Junta de Coordinación y Régimen Interior de la Defensoría del Pueblo deberá conocer e informar sobre la posible interposición de recursos de amparo e inconstitucionalidad ante el Tribunal Constitucional, siendo habitual, como destacan varios autores, que el Defensor del Pueblo solicite también informes externos antes de adoptar la decisión de plantear un recurso de inconstitucionalidad $^{83}$. No obstante, la decisión final sobre la interposición del recurso corresponde únicamente al Defensor del Pueblo, tal y como se desprende del texto constitucional, la LOTC y la LODP, de modo que la interposición del recurso en este caso depende únicamente del criterio y la voluntad del titular de la institución ${ }^{84}$.

En cuanto al alcance de la legitimación activa reconocida al Defensor del Pueblo, es de reseñar que ni la Constitución, ni la LOTC o la LODP, limitan la facultad del Defensor en función del contenido de la norma a impugnar. De este modo, aunque algún autor ha defendido que la legitimación del Defensor debía restringirse a aquellas normas que tuvieran directa conexión con la función constitucional que le atribuía el artículo $54 \mathrm{CE}$, esto es, la defensa de los derechos reconocidos en el Título I CE ${ }^{85}$, la realidad es que hoy parece indefendible la limitación de la facultad del Defensor del Pueblo por razón de la materia ${ }^{86}$. En este sentido se ha pronunciado claramente el Tribunal Constitucional $^{87}$, que ha reconocido que la legitimación del Defensor del Pueblo para interponer recursos de inconstitucionalidad no está sujeta "a límites o condiciones objetivas de ningún tipo", debiendo entenderse "en los mismos términos y con la misma amplitud que la del resto de los sujetos contemplados conjuntamente en los artículos 162.1.a) CE y 32.1 LOTC" ${ }^{88}$.

La atribución al Defensor del Pueblo de facultades equiparables a las del Presidente del Gobierno o la minoría parlamentaria en lo que al planteamiento de la inconstitucionalidad de las leyes se refiere suscita así importantes dudas. Si no parecen convincentes los argumentos que apoyan la configuración del Defensor del Pueblo como una suerte de guardián de la Constitución, ni como el vínculo que permitiría acercar el Tribunal Constitucional a la ciu-

82 En este sentido: LUNA ABELLA, C.: op. cit., págs. 743 y ss

83 PÉREZ-UGENA y COROMINA, M.: op. cit., págs. 293 y ss.

84 En este sentido: LUNA ABELLA, C.: op. cit., págs. 743 y ss.; PÉREZ-UGENA y COROMINA M.: op. cit., pág. 298; GARCÍA MARTÍNEZ, A.: El recurso de inconstitucionalidad. El proceso directo de inconstitucionalidad, Trivium, Madrid, 1992, pág. 153.

85 En este sentido: ARAGÓN REYES, M.: "Artículo 162. Legitimación en los procesos constitucionales", en ALZAGA VILLAMIL, O.: Comentarios a la Constitución Española de 1978, Editoriales de Derecho Reunidas, Madrid, 1999, pág. 260; VARELA SUANZES-CARPEGNA, J.: "La naturaleza jurídica del Defensor del Pueblo", Revista Española de Derecho Constitucional, núm. 8, 1983, págs. 68 y ss. y 78 y ss.

86 En este sentido: LUNA ABELlA, C.: op. cit., págs. 746 y ss.; CARBALlO ARMAS, P.: op. cit., pág. 159; PÉREZ-UGENA y COROMINA, M.: op. cit., pág. 298.

87 STC 274/2000, de 15 de noviembre; STC 150/1990, de 4 de octubre.

88 STC 274/2000, de 15 de noviembre, FJ 2. 
dadanía, y la facultad atribuida al Defensor del Pueblo no se vincula con la función que la Constitución le atribuye, tan sólo un último argumento, también apuntado por parte de la doctrina española, podría justificar la atribución a esta institución de la facultad de interponer el recurso de inconstitucionalidad: la apertura del recurso de inconstitucionalidad a un órgano de carácter más neutro que el del resto de los legitimados para plantearlo, esto es, a un órgano que por su carácter independiente y alejado de la lógica partidista, habría de utilizar la facultad que le atribuye la Constitución basándose en criterios objetivos y estrictamente jurídicos ${ }^{89}$

Sin embargo, esta última justificación ha sido puesta en tela de juicio por aquellos autores que han señalado, en un sentido diametralmente distinto, que el ejercicio de esta facultad por el Defensor podría llevar a politizar e integrar en la lógica ordinaria del debate político a una institución cuya aportación al sistema constitucional se basa, precisamente, en la auctoritas y la independencia de quien la encabeza ${ }^{90}$. La cuestión podría quizás plantearse en términos más amplios, en la medida en que si reconocemos que el control de la constitucionalidad del producto legislativo implica casi siempre ciertas connotaciones políticas, parece que podremos también cuestionar si la activación de ese control no es, en sí mismo, un acto de profundas dimensiones políticas. Dada la relevancia de este debate, parece oportuno analizar cómo ha utilizado el Defensor del Pueblo la facultad que le ha atribuido la Constitución a fin de observar qué criterios ha utilizado la institución en el ejercicio de su facultad y cómo ha podido influir la actuación del Defensor del Pueblo en la vida pública española.

\section{III.3. LA CUESTIÓN PRÁCTICA: ¿CÓMO HA UTILIZADO EL DEFENSOR DEL PUEBLO LA FACULTAD DE INTERPONER EL RECURSO DE INCONSTITUCIONALIDAD?}

El Defensor del Pueblo no ha planteado, hasta la fecha en que se cierra este trabajo, un número excesivo de recursos de inconstitucionalidad, habiéndose limitado a interponer un total de 23 recursos, cuyos resultados han sido muy diversos: 9 recursos han sido estimados, bien en su totalidad o en parte; 7 recursos han sido desestimados; el Defensor del Pueblo ha desistido de 2; 1 se ha extinguido; y 4 recursos están todavía pendientes. Estos números denotan una evidente moderación de la institución en el ejercicio de la facultad que le atribuye el artículo 162.1.a) de la Constitución. No obstante, la constatación de esta moderación no es suficiente para valorar la activi-

89 En este sentido: PÉREZ-UGENA y COROMINA, M.: op. cit., págs. 300 y ss.; VINTRÓ CASTELLS, J.: op.cit., pág. 411. También parece ir en la misma línea: GARCÍA MARTÍNEZ, A.: op. cit., pág. 153.

90 En este sentido: TORRES MURO, I.: op. cit., págs. 41 y ss; GIL ROBLES Y GIL DELGADO, A.: op. cit., pág. 314; ARAGÓN REYES, M.: op. cit., pág. 266; VINTRÓ CASTELLS, J.: op. cit., pág. 411; PÉREZ-UGENA y COROMINA, M.: op. cit., págs. 300 y ss. 
dad de la Defensoría, ya que parece necesario tratar de identificar los criterios que han sido utilizados para determinar cuando procedía utilizar esta facultad.

En relación con esta cuestión, resulta de especial trascendencia el primer Informe presentado por el Defensor del Pueblo ante las Cortes Generales ${ }^{91}$. En ese Informe, en el que se recogía la actividad de la institución durante el año 1983, se hacía referencia al carácter amplísimo e incondicionado con que la Constitución y la LOTC definían la facultad del Defensor de acudir en amparo y por la vía del recurso de inconstitucionalidad ante el Tribunal Constitucional ${ }^{92}$. Esa falta de limitación legal, consideraba el Defensor, imponía a la institución ciertas dosis de temple y moderación en el ejercicio de las facultades que le atribuía la Constitución, a fin de "no interferir en los cauces institucionales por donde se deben canalizar las discrepancias políticas ${ }^{93}$. En relación con el recurso de inconstitucionalidad, el Defensor del Pueblo reseñaba que, como criterio "provisional", la institución había decidido plantear el recurso de inconstitucionalidad en su primer año de funcionamiento tan sólo cuando ningún otro legitimado hubiera instado la acción y el Defensor del Pueblo considerara que la Ley o norma con rango de ley implicada infringía de forma "patente" los derechos y libertades definidos en la Constitución ${ }^{94}$.

En su Informe de 1988, el Defensor del Pueblo añadía un criterio adicional que habría de guiar las decisiones de la institución sobre la interposición de recursos de inconstitucionalidad, al indicar expresamente su intención de no plantear el recurso cuando su solicitud se centrara en cuestiones competenciales, al entender que "en este supuesto tanto las Comunidades Autónomas como el Gobierno de la Nación tienen conferida legitimación suficiente para acudir al Tribunal Constitucional en defensa de sus propios intereses, ${ }^{95}$. Posteriormente, la institución extendió ese criterio de forma expresa a aquellas peticiones que planteaban cuestiones competenciales referidas a los entes locales, al caracterizarlas como "otro tipo de conflicto competencial" ${ }^{96}$; destacando que esa afirmación se realizara incluso antes de que se modificara la LOTC a fin de incluir el conflicto en defensa de la autonomía local.

91 Defensor del Pueblo, Informe a las Cortes Generales, 1983.

92 Ibidem, pág. 20.

93 Idem supra.

94 Idem supra. En la misma línea: Defensor del Pueblo, Informe anual 1988 y debates en las Cortes Generales, 1989, pág. 324; Defensor del Pueblo, Informe a las Cortes Generales, 1986, págs. 526-527.

95 Defensor del Pueblo, Informe anual 1988 y debates en las Cortes Generales, 1989, pág. 324. Varios Informes del Defensor del Pueblo se pronuncian en el mismo sentido, entre otros: Defensor del Pueblo, Informe anual 2007 y debates en las Cortes Generales, 2008, pág. 1589; Defensor del Pueblo, Informe anual 2001 y debates en las Cortes Generales, 2002, págs. 652, 697; Defensor del Pueblo, Informe anual 1998 y debates en las Cortes Generales, 1999, págs. 593, 638, 642.

96 Este posicionamiento se observa de forma clara y expresa en: Defensor del Pueblo, Informe anual 1998 y debates en las Cortes Generales, 1999, págs. 724 y ss. 
Estos criterios plasmaban dos opciones claras de la Defensoría: su pretensión de recurrir únicamente en última instancia, esto es, siempre de forma subsidiaria en relación con el resto de los sujetos legitimados para hacerlo; y su pretensión de limitar su acción al ámbito de los derechos constitucionalmente reconocidos, esto es, de vincular la facultad que le reconocía la Constitución a la función principal que le atribuía el artículo 54 del texto constitucional, véase, la garantía de los derechos del Título I de la Constitución.

Siguiendo estos criterios, los Informes anuales de la institución han informado detalladamente de la negativa del Defensor del Pueblo a plantear recursos de inconstitucionalidad cuando la solicitud se había presentado fuera del plazo para interponer el recurso ${ }^{97}$; cuando se solicitaba la interposición del recurso contra una norma que no era Ley o no tenía rango de Ley ${ }^{98}$; cuando el recurso ya había sido planteado por otro órgano legitimado para hacerlo9; o cuando el Defensor del Pueblo entendía que la norma no vulneraba los derechos constitucionalmente reconocidos ${ }^{100}$ o alguna otra norma constitucional ${ }^{101}$. No obstante, en aquellos casos en los que la institución entendía que

97 Prácticamente todos los informes anuales del Defensor del Pueblo dan cuenta del rechazo de solicitudes de interposición del recurso de inconstitucionalidad por este motivo. Algunos ejemplos pueden encontrarse en: Defensor del Pueblo, Informe anual 2000 y debates en las Cortes Generales, 2001, pág. 512; Defensor del Pueblo, Informe anual 1992 y debates en las Cortes Generales, 1993, pág. 965; Defensor del Pueblo, Informe a las Cortes Generales, 1984, pág. 250.

98 En este sentido, entre otros: Defensor del Pueblo, Informe anual 1989 y debates en las Cortes Generales, 1990, pág. 537; Defensor del Pueblo, Informe a las Cortes Generales, 1987, pág. 18; Defensor del Pueblo, Informe a las Cortes Generales, 1985, pág. 40.

99 Varios informes anuales del Defensor del Pueblo dan cuenta del rechazo de solicitudes de interposición del recurso de inconstitucionalidad por este motivo. Algunos ejemplos pueden encontrarse en: Defensor del Pueblo, Informe anual 2009 y debates en las Cortes Generales, 2010, págs. 1703, 1729; Defensor del Pueblo, Informe anual 2001 y debates en las Cortes Generales, 2002, pág. 660; Defensor del Pueblo, Informe a las Cortes Generales, 1987, pág. 22; Defensor del Pueblo, Informe a las Cortes Generales, 1983, pág. 114.

100 Todos los informes anuales del Defensor del Pueblo dan cuenta del rechazo de solicitudes de interposición del recurso de inconstitucionalidad por este motivo. Algunos ejemplos pueden encontrarse en: Defensor del Pueblo, Informe anual 2009 y debates en las Cortes Generales, 2010, págs. 1664-1695; Defensor del Pueblo, Informe anual 2000 y debates en las Cortes Generales, 2001, págs. 430-448, 460-468, 479-493, 495-508; Defensor del Pueblo, Informe anual 1993 y debates en las Cortes Generales, 1994, págs. 1096-1134; Defensor del Pueblo, Informe a las Cortes Generales, 1987, pág. 19; Defensor del Pueblo, Informe a las Cortes Generales, 1986, págs. 2932.

101 Todos los informes anuales del Defensor del Pueblo dan cuenta del rechazo de solicitudes de interposición del recurso de inconstitucionalidad por este motivo. En este sentido, es de destacar que se ha solicitado el planteamiento de un recurso de inconstitucionalidad por parte del Defensor del Pueblo de forma reiterada cuando se entendían violados los preceptos constitucionales más diversos. Sin ánimo de realizar un análisis exhaustivo, es de destacar que se ha solicitado la interposición del recurso por el Defensor cuando se entendía que la norma violaba los principios de los arts. 9 ó 103 CE, ver entre otros: Defensor del Pueblo, Informe anual 2007 y debates en las Cortes Generales, 2008, págs. 1541-1555, 1570-1578; Defensor del Pueblo, Informe anual 2000 y debates en las Cortes Generales, 2001, págs. 430-434, 460-468, 495-508. También se ha solicitado el planteamiento del recurso en relación con el marco constitucional de distribución de competencias entre el Estado y las CCAA o con otras disposiciones constitucionales que regulan el Estado de las Autonomías, ver entre otros: Defensor del Pueblo, Informe anual 2009 y 
una incorrecta aplicación de la norma podía dar lugar a alguna vulneración de los derechos del Título I de la Constitución, el Defensor dirigía recomendaciones a la autoridad competente ${ }^{102}$.

Siguiendo también la política explicitada por la propia institución, en los primeros años de funcionamiento de la Defensoría, el Defensor del Pueblo interpuso recursos de inconstitucionalidad únicamente contra leyes o normas con rango de ley que consideraba violaban alguno de los derechos reconocidos en el Título I de la Constitución ${ }^{103}$.

debates en las Cortes Generales, 2010, págs. 1710, 1716-1727; Defensor del Pueblo, Informe anual 1992 y debates en las Cortes Generales, 1993, págs. 910-913, 919-923, 926-932; Defensor del Pueblo, Informe anual 1988 y debates en las Cortes Generales, 1989, págs. 328. También se ha solicitado la interposición del recurso en relación con la utilización que han realizado las instituciones de nuestro sistema de fuentes del Derecho, ver entre otros (en relación con la utilización del Decreto Ley): Defensor del Pueblo, Informe anual 2000 y debates en las Cortes Generales, 2001, págs. 493-495, 507-514; (en relación con Leyes de carácter singular): Defensor del Pueblo, Informe anual 1992 y debates en las Cortes Generales, 1993, págs. 923-926; (en relación con el contenido de las Leyes de Presupuesto): Defensor del Pueblo, Informe anual 2009 y debates en las Cortes Generales, 2010, págs. 1644-1701; (en relación con los Decretos Legislativos): Defensor del Pueblo, Informe anual 2000 y debates en las Cortes Generales, 2001, págs. 477-480; e incluso sobre supuestas deficiencias procedimentales que se habrían producido en la tramitación parlamentaria de una Ley: Defensor del Pueblo, Informe anual 1993 y debates en las Cortes Generales, 1994, págs. 1105-1111.

102 En muchos Informes anuales del Defensor del Pueblo se puede rastrear la utilización de esta facultad, entre otros ver: Defensor del Pueblo, Informe anual 2001 y debates en las Cortes Generales, Informe, 2002,pág. 660; Defensor del Pueblo, Informe anual 1991 y debates en las Cortes Generales, Informe, 1992, pág. 916; Defensor del Pueblo, Informe a las Cortes Generales, 1983, págs. 251, 252.

103 En 1983, se interpuso recurso contra la Ley 9/1983, de 13 de julio, de Presupuestos Generales del Estado para 1983, por entender que vulneraba los arts. 28 y 14 CE (Resuelto por STC 20/1985 en sentido estimatorio). En 1984, se interpuso un recurso semejante y por idénticos motivos contra la Ley 44/1983, de 28 de diciembre, de Presupuestos Generales del Estado para 1984 (Resuelto por STC 26/1985 en sentido estimatorio). En 1985, el Defensor del Pueblo interpuso un número mayor de recursos (6): contra la Ley 50/1984, de 30 de diciembre, de Presupuestos Generales del Estado para 1985, por presunta vulneración de los arts. 28 y 7 CE (Resuelto por STC 72/1985 en sentido estimatorio); contra la Ley 15/1984, de 19 de diciembre, reguladora del Fondo de Solidaridad Municipal de Madrid, adoptada por la Comunidad de Madrid, por entender que violaba los arts. 31 y 9 CE (Resuelto por STC 150/1990 en sentido desestimatorio); contra las Ley 48/1984, de 26 de diciembre, reguladora del derecho de objeción de conciencia y de la prestación social sustitutoria, y la Ley Orgánica 8/1984, de 26 de diciembre, reguladora del régimen de recursos en caso de objeción de conciencia, su régimen penal y otros extremos, por entender que vulneraban los arts. 9.3, 10, 16, 18.1, 14, 30.2, 53, 81 y 96 CE (Resuelto por STC 160/1987 en sentido desestimatorio); contra la Ley Foral 21/1984, de 29 de diciembre, de Presupuestos Generales de Navarra para el ejercicio de 1985, por considerar que vulneraba los arts. 28 y 7 CE (el Defensor del Pueblo desistió de este recurso cuando la Comunidad Autónoma decidió modificar el precepto recurrido, ATC 636/1985); contra la Ley Orgánica 7/1985, de 1 de julio, sobre derechos y libertades de los extranjeros en España, por entender que violaba los arts. 14,16,17,21,22,24,25, y 53.2 CE (Resuelto por STC 115/1987 en sentido parcialmente estimatorio); contra la Ley Orgánica 11/1985, de 2 de agosto, de Libertad Sindical, por entender que vulneraba los arts. 81,53 y $28 \mathrm{CE}$ (Resuelto por STC 101/1991 en sentido desestimatorio). En 1986, el Defensor del Pueblo tan sólo interpuso dos recursos de inconstitucionalidad, contra la Ley del Parlamento de Cataluña 22/1985, de 8 de noviembre, sobre creación del Colegio Profesional de Periodistas de Cataluña, por en- 
Sin embargo, esa opción parece comenzar a quebrarse a partir de $1997^{104}$, año en el que el Defensor del Pueblo interpone dos recursos de inconstitucionalidad de dimensión un tanto compleja, en la medida en que en uno de ellos se planteaba la eventual inconstitucionalidad de la reforma del sistema electoral aplicable a las elecciones del Parlamento canario, contenida en el Estatuto de Autonomía de esa Comunidad; y en el otro, se planteaba la eventual inconstitucionalidad de la Ley de Presupuestos de esa Comunidad Autónoma para el año 1997, al entender el Defensor del Pueblo que la ley presupuestaria no respetaba las exigencias materiales impuestas por el bloque de constitucionalidad español al exceder en su contenido el límite de materias que podían ser reguladas por la Ley de Presupuestos de una Comunidad Autónoma.

Si bien la supuesta inconstitucionalidad del régimen electoral canario se vinculaba, a ojos del Defensor del Pueblo, con los artículos 14 y 23 CE y, por tanto, con la posible vulneración del derecho de los ciudadanos a acceder a cargos y funciones públicas en condiciones de igualdad, parecía claro que el Defensor del Pueblo era consciente de la quiebra de su política general con la interposición del segundo recurso, ya que en su Informe anual a las Cortes señalaba que se había considerado oportuno la interposición de ese segundo recurso:

tender que vulneraba los arts. 20.1 d), 13.1, 14, 139.1 y 139.2 y $149.1 .1 \mathrm{CE}$ (el Defensor del Pueblo desistió de este recurso cuando la Comunidad Autónoma decidió modificar el precepto recurrido, ATC 812/1988); y contra la Ley 4/1986, de 8 de enero, sobre Cesión de Bienes del Patrimonio Sindical Acumulado, por entender que vulneraba los arts. 7,28,14 y 9.3 CE (Resuelto por STC 75/1992 en sentido desestimatorio). Desde 1987 hasta 1993, el Defensor del Pueblo no vuelve a interponer ningún recurso de inconstitucionalidad. En ese año se interpone un único recurso, contra la Ley Orgánica 5/1992, de 29 de octubre, de Regulación del Tratamiento Automatizado de los Datos de Carácter Personal, por entender que la misma violaba los arts. 18.1, 18.4 y 53.1 CE (Resuelto por STC 290/2000). En el año 1994, el Defensor del Pueblo también planteó un sólo recurso de inconstitucionalidad contra la Ley 9/1994, de 19 de mayo, de modificación de la Ley 5/1984, reguladora del derecho de asilo y de la condición de refugiado, al entender que vulneraba los arts. 17, 53.1 y 81 CE (Resuelto por STC 53/2000 en sentido desestimatorio). En el año 1996, el Defensor del Pueblo vuelve a interponer un único recurso de inconstitucionalidad contra la Ley 1/1996, de Asistencia Jurídica Gratuita, por entender que la misma violaba el art. 24 y el art. 53.1 CE (Resuelto por STC 95/2003 en sentido parcialmente estimatorio).

104 En el año 1997, el Defensor del Pueblo interpone dos recursos de inconstitucionalidad, contra el Estatuto de Autonomía de Canarias, en la versión dada por la Ley Orgánica 4/1996, de 30 de diciembre, al entender que el sistema electoral diseñado por la norma para las elecciones al Parlamento canario no era proporcional, incumpliendo las exigencias marcadas por los arts. $1.1,6,9.2,9.3,14,23.2$ y 152.1 CE (Resuelto por STC 225/1998 en sentido desestimatorio): y contra diversas disposiciones de la Ley del Parlamento de Canarias 5/1996, de 27 de diciembre, de Presupuestos Generales de la Comunidad Autónoma para 1997, por entender que violaba el artículo 9.3 de la Constitución y los artículos 61.1 .b) del Estatuto de Autonomía de Canarias, aprobado por Ley Orgánica 10/1982, de 10 de agosto, y reformado por la Ley Orgánica 4/1996, de 30 de diciembre, y 21.1 de la Ley Orgánica 8/1980, de 22 de septiembre, de Financiación de las Comunidades Autónomas (Resuelto por STC 274/2000 en sentido parcialmente estimatorio). Una exposición completa de los argumentos utilizados por el Defensor del Pueblo para justificar la interposición del recurso se encuentran en: Defensor del Pueblo, Informe anual 1997 y debates en las Cortes Generales, 1998, págs. 536-566. 
"(...) al considerar su objeto como idóneo en relación con la misión de defensa de los derechos contenidos en el título I de la Constitución que el artículo 54 de la misma encomienda al Defensor del Pueblo. En definitiva, entendemos que delimitar el marco constitucionalmente válido en el que la comunidad autónoma puede ejercitar su poder financiero y concretar la intensidad con la que el principio de legalidad presupuestaria y sus derivaciones se aplican a ésta, con el rigor y precisión de la doctrina de ese tribunal (referencia al Tribunal Constitucional), contribuirá significativamente a la garantía del espacio de libertad del que deben disponer los ciudadanos frente a todo ejercicio del poder político " ${ }^{105}$.

El Defensor del Pueblo añadía a su argumento principal motivos subsidiarios de posible inconstitucionalidad de uno de los preceptos de la Ley, estos sí vinculados con la eventual vulneración de los artículos 23.2 y 103.3 CE, aunque también con la presunta falta de respeto a la legislación básica del Estado en materia de función pública. No obstante, el argumento central giraba claramente en torno al exceso material de la Ley de Presupuestos de la Comunidad Autónoma.

En el año $1998^{106}$, la quiebra de la política tradicional de la institución en cuanto a la interposición de recursos de inconstitucionalidad se hacía todavía más evidente, al plantearse un recurso contra el artículo 8. 1 de la Ley 8/1997, de 9 de diciembre, de Horarios Comerciales de la Comunidad Valenciana, sobre un motivo únicamente competencial. El Defensor del Pueblo, consciente del cambio de criterio en la actuación de la institución, señalaba los motivos que le habían llevado a plantear el recurso haciendo referencia a la excepcionalidad del caso por dos motivos, a saber: "La petición efectuada por el compareciente no se funda en un problema competencial, sino en la discriminación que sufren los panaderos valencianos respecto de los del resto del territorio nacional al no poder ejercer su actividad los domingos y festivos" y que «El Tribunal Constitucional ya se ha pronunciado sobre un conflicto normativo virtualmente idéntico en su sentencia 225/1993 (...)” ${ }^{107}$. 562.

105 Defensor del Pueblo, Informe anual 1997 y debates en las Cortes Generales, 1998, pág.

106 En ese año, el Defensor del Pueblo interpuso recursos de inconstitucionalidad contra un precepto de la Ley 6/1989, de 6 de julio, de la Función Pública Vasca, añadido por el artículo 10 de la Ley de la Comunidad Autónoma del País Vasco 16/1997, de 7 de noviembre, por estimar que dicho precepto vulneraba los artículos 23.2, 103.3 y 149.1.18 CE (Resuelto por STC 31/2006 en sentido estimatorio): y contra la Ley 8/1997, de 9 de diciembre, de la Generalidad Valenciana, de Horarios Comerciales de la Comunidad Valenciana, al estimar que un precepto de la misma vulneraba el art. 149.1.13 CE y el art. 3 de la Ley Orgánica 2/1996, de 15 de enero, complementaria de la de Ordenación del Comercio Minorista (Resuelto por ATC 9/2005, que declara extinguido el recurso por haberse producido la pérdida sobrevenida del objeto del mismo). Sobre los argumentos empleados por la institución para defender la inconstitucionalidad de tales normas, ver: Defensor del Pueblo, Informe anual 1998 y debates en las Cortes Generales, 1999, págs. 570590. 582.

107 Defensor del Pueblo, Informe anual 1998 y debates en las Cortes Generales, 1999, pág. 
No se produce una nueva quiebra de los criterios de la institución sobre la interposición de recursos de inconstitucionalidad hasta el año $2006^{108}$, en el que el Defensor del Peublo decide interponer un recurso de inconstitucionalidad contra numerosos preceptos del Estatuto de Autonomía de Cataluña, a la par que otros legitimados para interponerlo ${ }^{109}$. A pesar de que el Defensor del Pueblo señalaba en su Informe a las Cortes Generales de ese año que la decisión de interponer el recurso se vinculaba a la posibilidad de que el Estatuto conculcara "los derechos comprendidos en el Título I de la Constitución y, en particular, el valor superior de la igualdad reconocido en el artículo 1.1,110, la realidad es que una revisión global de los preceptos impugnados del Estatuto y de la motivación ofrecida por el recurso del Defensor demuestran que la intencionalidad del recurso no fue "exclusivamente" la defensa de los derechos comprendidos en el Título I de la Constitución. Sin ánimos de realizar un estudio detallado de los motivos de inconstitucionalidad alegados por el Defensor del Pueblo destaca, por ejemplo, que la institución impugnara el artículo 2.4 del Estatuto, que señala que "Los poderes de la Generalitat emanan del pueblo de Cataluña y se ejercen de acuerdo con lo establecido en el presente Estatuto y la Constitución", por contravenir los artículos 1.2 y 2 CE, que atribuyen la soberanía nacional al pueblo español y afirman la indisoluble unidad de la nación española; o que se impugnaran numerosos preceptos del Estatuto referidos al poder judicial y la Administración de Justicia por contra-

108 En 1999, se interpuso un único recurso de inconstitucionalidad por el Defensor del Pueblo en relación con un precepto de la Ley 49/1998, de 30 de diciembre, de Presupuestos Generales del Estado para 1999, que se entendía infringía el principio de interdicción de la arbitrariedad de los poderes públicos y los principios de igualdad ante la ley y de asignación equitativa de los recursos públicos que recogen los artículos 14 y 31.2 CE (Resuelto por STC 45/2007 en sentido desestimatorio). En el año 2000, se interpuso un único recurso contra la Ley Orgánica 15/1999, de 13 de diciembre, de Protección de Datos de Carácter Personal, por estimar que vulneran el artículo 18.4 en relación con el 18.1 y el artículo 53.1 CE (Resuelto por STC 292/2000 en sentido estimatorio).

109 Es de recordar, en este sentido, que se han interpuesto otros recursos contra la Ley Orgánica 6/2006, de 19 de julio, de reforma del Estatuto de Autonomía de Cataluña: el 31 de julio de 2006 se registró la entrada del recurso interpuesto por más de 50 diputados del Grupo Parlamentario Popular (Resuelto por STC 31/2010 en sentido parciamente estimatorio); el 25 de septiembre de 2006, el Gobierno de la Comunidad Autónoma de Murcia interpuso recurso contra la Ley Orgánica indicada (Admitido por Providencia de 24 de octubre de 2006, recurso núm. 88292006); el 11 de octubre de 2006, presentó su recurso el Gobierno de la Comunidad Autónoma de La Rioja (Admitido por Providencia de 24 de octubre de 2006, recurso núm. 9330-2006); el 19 de octubre de 2006 presentó su recurso el Consell de la Generalitat de la Comunitat Valenciana (Admitido por 8 de noviembre de 2006, se admitió a trámite el recurso de inconstitucionalidad núm. 9501-2006); el 19 de octubre de 2006 presentó su recurso el Gobierno de la Diputación General de Aragón (Admitido por Providencia de 8 de noviembre de 2006, recurso núm. 9491-2006); y el 20 de octubre de 2006 presentó su recurso el Gobierno de las Illes Balears (Admitido por Providencia de 8 de noviembre de 2006, recurso núm. 9501-2006). El Defensor del Pueblo presentó su recurso el día 19 de septiembre de 2006, de modo que lo hizo conociendo ya la interposición del mismo por un Grupo de Diputados.

110 Defensor del Pueblo, Informe anual 2006 y debates en las Cortes Generales, 2007, pág. 911. 
venir variadas disposiciones constitucionales sobre la distribución de competencias entre el Estado y las Comunidades Autónomas y la configuración constitucional del Poder Judicial.

Si bien en el año 2007, el Defensor del Pueblo no planteó ningún recurso de inconstitucionalidad, en el año 2008 la institución plantea dos recur$\operatorname{sos}^{111}$, que vuelven a quebrar, aunque no de una forma tan evidente, la política general de la Defensoría, al interponerse contra sendas disposiciones de la Ley 51/2007, de 26 de diciembre, de Presupuestos Generales del Estado para 2008, y de la Ley 15/2007, de 27 de diciembre, de la Generalitat Valenciana, de Presupuestos para el ejercicio 2008, por contravenir los límites materiales que, según jurisprudencia constitucional reiterada, deben cumplir las Leyes de Presupuestos. Si bien en el primer caso el recurso planteado no parecía poder vincularse con ninguno de los derechos reconocidos en el Título I de la Constitución, en la medida en que la disposición impugnada alteraba un requisito de cualificación para el acceso al cuerpo superior de auditores, uno de los cuerpos especiales del Tribunal de Cuentas; en el segundo caso, sí parecía poderse encontrar tal vínculo, en la medida en que la disposición impugnada regulaba el régimen del silencio administrativo en los procedimientos para el reconocimiento de la situación de dependencia y del derecho a las prestaciones del sistema valenciano para las personas dependientes; cuestión que la propia Defensoría del Pueblo parecía vincular con los artículos 49 y $50 \mathrm{CE}^{112}$.

Finalmente, el Defensor del Pueblo ha interpuesto un último recurso de inconstitucionalidad ${ }^{113}$ contra varios preceptos de la Ley del Parlamento de Cataluña 24/2009, de 23 de diciembre, del Síndic de Greuges, por motivos que, a la espera de lo que indique la propia institución en su Informe anual de 2010, no parecen tener nada que ver con la protección de los derechos reconocidos en el Título I de la Constitución, aunque sí con la salvaguarda de las propias competencias de la institución ${ }^{114}$.

Analizada la utilización que ha realizado la Defensoría del Pueblo de la facultad que le otorga el artículo 162.1.a) de la Constitución, parece poder

111 En el año 2008, el Defensor del Pueblo interpuso dos recursos de inconstitucionalidad, que están pendientes de ser resueltos por el Tribunal Constitucional: contra la Disposición adicional sexagésima de la Ley 51/2007, de 26 de diciembre, de Presupuestos Generales del Estado para el año 2008; y contra la Disposición adicional undécima de la Ley 15/2007, de 27 de diciembre, de la Generalitat Valenciana, de Presupuestos para el ejercicio 2008. Los motivos que llevaron al Defensor del Pueblo a plantear esos recursos pueden verse en: Defensor del Pueblo, Informe anual 2008 y debates en las Cortes Generales, 2009, págs. 1673 y ss. 1673.

112 Defensor del Pueblo, Informe anual 2008 y debates en las Cortes Generales, 2009, pág.

113 En el año 2010, el Defensor del Pueblo interpuso un único recurso en relación con diversos preceptos de la Ley del Parlamento de Cataluña 24/2009, de 23 de diciembre, del Síndic de Greuges.

114 Así parece desprenderse de los preceptos de la Ley que han sido impugnados (arts. 1.b); 3.1; 26.b), inciso "la Administración local", y c), inciso "O a la Administración local", y 68 a 78 de la Ley), todos ellas referidas al alcance de las competencias de la institución y a la configuración de sus relaciones con el Defensor del Pueblo. 
afirmarse que la institución, consciente de la relevancia política que tiene el ejercicio de la facultad que el texto constitucional le ha conferido, ha tendido a realizar un uso de la misma vinculado con la función principal que se le ha atribuido, esto es, la defensa de los derechos reconocidos en la Constitución. Sin embargo, esa política no siempre se ha seguido de forma estricta, de modo que la institución ha utilizado su facultad para interponer recursos de inconstitucionalidad por motivos totalmente ajenos a la defensa de los derechos reconocidos por la Constitución y, en ocasiones, claramente vinculados con intereses ajenos a su función principal.

Este sería el caso de los recursos interpuestos por el Defensor por motivos estrictamente competenciales, esto es, en relación con la distribución de competencias entre el Estado español y las Comunidades Autónomas. Aunque la institución ha tratado de justificar la interposición de esos recursos por motivos vinculados a la defensa de la igualdad y la no discriminación del conjunto de los ciudadanos españoles, la realidad es que esa motivación parece poco convincente si se tiene en cuenta el contenido de las disposiciones impugnadas y que la institución no ha interpuesto recurso de inconstitucionalidad contra normas que son muy semejantes — por no decir idénticas_ a aquellas que sí han sido impugnadas. Tal sería el caso, por ejemplo, de ciertos preceptos de la Ley Orgánica 2/2007, de 19 de marzo, de reforma del Estatuto de Autonomía para Andalucía, que el Defensor del Pueblo no ha recurrido a pesar de su semejanza con ciertos preceptos del Estatuto de Autonomía de Cataluña. La institución ha tratado de explicar el porqué de su actuación indicando que la sentencia del Tribunal Constitucional sobre el recurso interpuesto produciría sus efectos sobre el resto de las normas de igual contenido y que, por tanto, entendía cumplida su función constitucional con la interposición de ese primer recurso contra la Ley de reforma del Estatuto catalán ${ }^{115}$, pero parece clara la falta de consistencia de un argumento que el propio Defensor ha utilizado en otras ocasiones precisamente para justificar la interposición del recurso de inconstitucionalidad contra normas de contenido semejante o idéntico a aquellas sobre las que ya se había pronunciado el Tribunal Constitucional.

La utilización de la facultad de interponer el recurso de inconstitucionalidad de forma totalmente alejada de las funciones de la institución parece convertir al Defensor en un actor político más del escenario español, enfrentado con mayorías parlamentarias ${ }^{116}$ por cuestiones que nada tienen que ver

115 En este sentido, ver los argumentos utilizados por el Defensor del Pueblo para rechazar la interposición del recurso de inconstitucionalidad contra la Ley Orgánica 2/2007, de 19 de marzo, de reforma del Estatuto de Autonomía para Andalucía y contra la Ley Orgánica 1/2007, de 28 de febrero, de reforma del Estatuto de Autonomía de las Illes Balears: Defensor del Pueblo, Informe anual 2007 y debates en las Cortes Generales, 2008, págs. 1601-1616.

116 Ver, por ejemplo, las críticas recibidas en sede parlamentaria y a propósito del debate sobre la actividad del Defensor del Pueblo durante el año 2005 por la institución por la interposición del recurso de inconstitucionalidad contra la Ley Orgánica 6/2006, de 19 de julio, de reforma del Estatuto de Autonomía de Cataluña: Defensor del Pueblo, Informe anual 2005 y debates en las Cortes Generales, Debates, 2006. 
con su función principal y que en nada contribuyen a consolidar la institución. Por ello parecería más coherente que nuestro texto constitucional impusiera como norma lo que el buen criterio de la propia institución ya ha utilizado, en la mayoría de los casos, como elemento de juicio, y vinculara así el ejercicio de esta facultad con la función principal de la institución, que no es otra que la defensa de los derechos del Título I del texto constitucional ${ }^{117}$.

\section{LA LEGITIMACIÓN ACTIVA DEL DEFENSOR DEL PUEBLO PARA PLANTEAR EL RECURSO DE AMPARO ANTE EL TRIBUNAL CONSTITUCIONAL: LA DECLARACIÓN DE INTENCIONES}

El artículo 162.1.b) de la Constitución española, junto a los artículos 29 LODP y 46 LOTC, enumeran los órganos legitimados para interponer el recurso de amparo ante el Tribunal Constitucional español, identificando al Defensor del Pueblo como uno de ellos. A través de este recurso, el Defensor del Pueblo podrá impugnar cualquier decisión o acto sin valor de ley de las Cortes Generales, las Asambleas Legislativas de las Comunidades Autónomas o sus órganos; cualquier disposición, acto jurídico, omisión o simple vía de hecho de los gobiernos y administraciones públicas españolas; o cualquier acto u omisión de los órganos jurisdiccionales españoles, siempre y cuando violen alguno de los derechos reconocidos en los artículos 14-29 CE y 30.2 CE.

Esta facultad, menos controvertida que la anteriormente estudiada y mucho más vinculada con la función de la propia institución del Defensor del Pueblo, ha sido escasamente utilizada por el Defensor, que apenas ha interpuesto 10 recursos de amparo en toda su andadura constitucional, por lo que parece interesante estudiar los motivos que llevaron a reconocer legitimación al Defensor del Pueblo para interponer el recurso de amparo ante el Tribunal Constitucional, la configuración actual de tal legitimación y los criterios que ha seguido la Defensoría para hacer uso de esta facultad; elementos que deberían permitirnos determinar si la escasa utilización de esta facultad se debe a su carácter prescindible, dada la amplia legitimación de que gozan los particulares para interponer el recurso, o a su deficiente configuración constitucional o legal.

\section{IV.1. LA LEGITIMACIÓN ACTIVA DEL DEFENSOR DEL PUEBLO PARA INTERPONER RECURSOS DE AMPARO EN EL DEBATE CONSTITUYENTE Y EN EL PROCESO DE ELABORACIÓN DE LA LOTC Y LA LODP}

Tal y como ya reseñamos en relación con la facultad del Defensor del Pueblo de interponer recursos de inconstitucionalidad, la atribución de idén-

117 En el mismo sentido apunta ESPÍN TEMPLADO, E.: "Comentario al artículo 32", en REQUEJO PAGÉS, J. L.: Comentarios a la Ley Orgánica del Tribunal Constitucional, Tribunal Constitucional, Madrid, 2001, pág. 475. 
tica facultad en relación con los recursos de amparo ante el Tribunal Constitucional se incorporó en el texto del Anteproyecto de Constitución y permaneció prácticamente invariada a lo largo de todo el iter parlamentario.

Efectivamente, tanto el artículo 46 como el artículo 153 del Anteproyecto de Constitución ${ }^{118}$ atribuían al Defensor del Pueblo la facultad para plantear recursos de amparo ante el Tribunal Constitucional, extendiendo las atribuciones de la institución a la interposición del recurso preferente y sumario ante tribunales ordinarios, que regulaba el artículo 45.2 del Anteproyecto. La extensión de la legitimación activa para plantear el recurso de amparo constitucional fue propuesta en varias enmiendas presentadas en el Congreso ${ }^{119}$. Sin embargo, tan sólo la enmienda núm. 779, a la que ya hemos hecho referencia ${ }^{120}$ y que fue presentada por UCD, defendió la necesidad de limitar la actuación del Defensor del Pueblo a funciones no jurisdiccionales, recortando todas las vías de acción ante los tribunales que le reconocía la Constitución.

Tal y como ya quedó indicado, la enmienda presentada por UCD no fue debatida en sede parlamentaria. No obstante, sí se realizaron ciertos retoques en el artículo 46 del Anteproyecto, en la medida en que ya desde el Informe de la Ponencia de la Comisión de la Comisión de Asuntos Constitucionales y Libertades Públicas del Congreso de los Diputados ${ }^{121}$ se eliminó la referencia que hacía ese precepto a la legitimación activa del Defensor del Pueblo para interponer el recurso de amparo ante el Tribunal Constitucional y el recurso preferente y sumario en defensa de ciertos derechos del Título I de la Constitución. El Informe de la Ponencia justificaba la eliminación por la traslación de la legitimación activa del Defensor para interponer "ciertos recursos" al artículo 153 del Anteproyecto. Sin embargo, ese precepto recogía la legitimación activa del Defensor para plantear los recursos de amparo e inconstitucionalidad ante el Tribunal Constitucional, pero no para plantear el recurso preferente y sumario que regulaba el artículo 45 del Anteproyecto. El Defensor del Pueblo acababa de perder, por tanto, una de las facultades de acción en defensa de los derechos fundamentales que el Anteproyecto de Constitución le reconocía, quizás con la finalidad de contentar a aquel sector del Congreso claramente, UCD — que había manifestado su total rechazo a reconocer facultades de acción en vía jurisdiccional a una institución que entendía debía centrarse en el control del actuar administrativo ${ }^{122}$.

118 Anteproyecto de Constitución, Boletín Oficial de las Cortes Generales, de 5 de enero de 1978, núm. 44, págs. 676 y 696.

119 Destaca, en este sentido, la enmienda núm. 736, del Sr. Ortí Bordás (UCD), en la que se proponía la extensión de la legitimación para interponer el recurso de amparo constitucional a un grupo de 25 diputados o senadores. Constitución española, Trabajos Parlamentarios. Cortes Generales, 1980, pág. 116.

120 Ver el apartado III.1 de este mismo trabajo

121 Anteproyecto de Constitución, Informe de la Ponencia, Boletín Oficial de las Cortes Generales, de 17 de abril de 1978, núm. 82, pág. 1550.

122 En el mismo sentido, ver: LUNA ABELLA, C.: op. cit., págs. 716 y ss. 
Este estado de cosas no sufriría modificación alguna a su paso por el Senado, y ello a pesar del importante rechazo que suscitó entre varios grupos de la Cámara el reconocimiento de ciertas facultades de acción en vía judicial al Defensor del Pueblo que, desde su punto de vista, debía configurarse como una magistratura de opinión o de persuasión. Más allá del interesante debate sobre la propia esencia y configuración de la institución, al que ya hemos hecho referencia, es de reseñar que una preocupación fundamental de buena parte de los Senadores fue impedir una coincidencia de funciones entre el Ministerio Fiscal y el Defensor del Pueblo, perfilando las competencias de cada una de estas instituciones, llamadas a garantizar los derechos de los ciudadanos y los derechos del Título I de la Constitución, respectivamente ${ }^{123}$. Puesto que la distinción entre ambas instituciones pasaba, en la mente de los Senadores que plantearon el problema, por eliminar las facultades de acción en vía jurisdiccional del Defensor del Pueblo ${ }^{124}$, las enmiendas presentadas con esa finalidad fueron rechazadas por los Grupos mayoritarios ${ }^{125}$. Sin embargo, sí prosperaron dos enmiendas, propuestas por UCD y el Sr. Gutiérrez Rubio (Grupo Mixto), que defendían la necesidad de legitimar al Ministerio Fiscal para interponer recursos de amparo ante el Tribunal Constitucional, a fin de equiparar esa institución con la del Defensor del Pueblo ${ }^{126}$. Curiosamente, lo que comenzó siendo un intento de reducir las facultades de una institución, terminó con una ampliación de las facultades de otra.

Tal y como ya subrayamos en relación con el recurso de inconstitucionalidad, los debates de la LOTC y de la LODP —al menos los que se han hecho públicos- no tienen excesivo interés desde el punto de vista de la configuración de la facultad del Defensor del Pueblo de plantear recursos de amparo ante el Tribunal Constitucional, más allá del debate general, que vuelve a reproducirse, sobre la propia configuración de la institución como magistratura de opinión/persuasión o como magistratura de acción.

Los debates parlamentarios indicados no parecían aportar, por tanto, excesiva luz sobre la justificación de la atribución de la facultad de interponer el recurso de amparo al Defensor del Pueblo. No obstante, el hecho de que el debate en el Senado girara en torno a la atribución de idéntica facultad al Ministerio Fiscal en razón de las específicas funciones que perseguía la institu-

123 En esta lógica se situaban cuatro enmiendas presentadas en el Senado: Enmienda núm. 40, presentada por el Grupo Parlamentario de Progresistas y Socialistas Independientes; Enmienda núm. 183, presentada por el Sr. Pedrol Rius (Grupo Parlamentario Mixto); Enmienda núm. 199, presentada por el Sr. Gutiérrez Rubio (Grupo Parlamentario Mixto): y Enmienda núm. 722, presentada por la UCD, en Constitución española, Trabajos Parlamentarios, Cortes Generales, 1980, págs. 2631 y ss.

124 En este sentido, ver el debate en torno a las enmiendas presentadas en el Diario del Sesiones del Senado, de 31 de agosto de 1978, núm. 47, págs. 2127 y ss.

125 El resultado de las votaciones puede verse en el Diario del Sesiones del Senado, de 31 de agosto de 1978, núm. 47, pág. 2133.

126 Enmienda núm. 215, presentada por el Sr. Gutiérrez Rubio (Grupo Parlamentario Mixto), y Enmienda núm. 763, presentada por la UCD, ambas en Constitución española, Trabajos Parlamentarios, Cortes Generales, 1980, págs. 2659 y ss. 
ción - la defensa de los derechos de los ciudadanos - parece llevar a pensar que la facultad se atribuyó al Defensor del Pueblo por considerarla necesaria para el ejercicio de las funciones que la Constitución le atribuía. En este sentido, parecía querer potenciarse la dimensión objetiva del recurso de amparo: si bien este recurso fue configurado, al menos inicialmente, como un recurso dirigido a satisfacer los intereses concretos de los particulares cuyos derechos habían sido vulnerados ${ }^{127}$, la legitimación institucional atribuida al Defensor del Pueblo y al Ministerio Fiscal se justificaría en el interés público que se esconde detrás de los pronunciamientos en vía de amparo ${ }^{128}$, interés público que parece adoptar una posición mucho más preeminente tras la reforma introducida por la Ley Orgánica 6/2007, de 24 de mayo, en la LOTC.

A pesar del vínculo existente entre las funciones de la institución y la facultad indicada, parte de la doctrina española ${ }^{129}$ ha señalado que esta facultad sería quizás poco útil o prescindible, en la medida en que la Constitución también atribuye la legitimación para interponer el recurso de amparo a todos aquellos que invoquen un interés legítimo, y, por tanto, serán los particulares los que habitualmente ejerzan la acción, sin necesidad de contar con la ayuda del Defensor del Pueblo o el Ministerio Fiscal. Esa primera objeción podría, efectivamente, explicar que el Defensor del Pueblo haya hecho una utilización tan escasa de la legitimación que le ofrece la Constitución. Sin embargo, otra posible explicación a esa escasísima utilización podría derivarse de la propia configuración del recurso de amparo y de las limitadas facultades de la institución para actuar ante los tribunales ordinarios, ya que —es de recordar-, los constituyentes rechazaron — sin explicación alguna - la posibilidad de legitimar al Defensor del Pueblo para actuar ante los tribunales ordinarios en defensa de los derechos fundamentales y esa falta de legitimación podría plantear algún problema en el caso de que la legitimación del Defensor del Pueblo para acudir ante el Tribunal Constitucional se vinculara —como de hecho ocurreal agotamiento de esa vía previa ante los tribunales ordinarios. Veamos.

\section{IV.2. LOS REQUISITOS QUE CONFIGURAN LA FACULTAD DE INTERPONER RECURSOS DE AMPARO POR EL DEFENSOR DEL PUEBLO}

Los artículos 162.1.b) de la Constitución, 46 LOTC y 29 LODP atribuyen legitimación activa al Defensor del Pueblo, así como al Ministerio Fiscal,

127 En este sentido: SÁNCHEZ MORÓN, M.: “La legitimación activa en los procesos constitucionales", Revista Española de Derecho Constitucional, núm. 9, 1983, págs. 35 y ss.

128 En este sentido: LUNA ABELLA, C.: op. cit., págs. 739 y ss.; ARAGÓN REYES, M.: op. cit., págs. 266-267; TORRES MURO, I.: op. cit., págs. 203 y ss.; FERNÁNDEZ FARRERES, G.: El recurso de amparo según la jurisprudencia constitucional, Marcial Pons, Madrid, 1994, págs. 237 y ss.; SÁNCHEZ MORÓN, M.: op. cit., págs. 35 y ss.; ALMAGRO NOSETE, J.: "Cuestiones de legitimación en el proceso constitucional de amparo", Revista de Derecho Político, n. ${ }^{\circ}$ 10, 1981, págs. 71 y ss.; CORDÓN MORENO, F.: El proceso de amparo constituciona, La Ley, Madrid, 1992, pág. 131.

129 En este sentido: TORRES MURO, I.: op. cit., págs. 224 y ss. 
para interponer recursos de amparo ante el Tribunal Constitucional. Para la interposición del recurso, no se exige que el Defensor cuente con la autorización del afectado por el acto vulnerador del derecho fundamental o que le sustituya en el ejercicio de su acción ${ }^{130}$, por lo que algunos autores parecen defender la posibilidad de que el Defensor pueda interponer el recurso incluso contra la voluntad del propio afectado por la medida ${ }^{131}$. La decisión de interponer el recurso recaería así únicamente sobre el Defensor del Pueblo, aunque, tal y como ya señalamos para el recurso de inconstitucionalidad, el artículo 18.1.b) del Reglamento de Organización y Funcionamiento del Defensor del Pueblo prevé que la Junta de Coordinación y Régimen Interior de la Defensoría del Pueblo deberá conocer e informar sobre la posible interposición de recursos de amparo ante el Tribunal Constitucional.

En cuanto a los requisitos de legitimación que se imponen al Defensor del Pueblo, es de destacar que la facultad del titular de la institución no se vincula a ningún requisito de legitimación ${ }^{132}$. Ha de entenderse así, que la legitimación del Defensor del Pueblo para plantear este recurso es incondicionada, en el sentido de que no se vincula a que el Defensor invoque un interés legítimo" (art. 162.1.b) CE), en el caso de que el recurso se plantee contra una decisión o acto sin valor de ley de las Cortes o sus órganos (art. 46 y 42 LOTC), o a que haya sido parte en el proceso judicial previo, en el caso de que el recurso se plantee contra actos del ejecutivo o del poder judicial (arts. 46, 43 y 44 LOTC).

Más allá de la inexistencia de requisito alguno de legitimación, cabe plantear si el recurso de amparo presentado por el Defensor del Pueblo deberá cumplir el resto de requisitos procesales exigidos por la LOTC. En principio, la pregunta debe responderse de forma afirmativa, dada la total ausencia de referencia expresa en contra en la LOTC. Sin embargo, hay que destacar que la aplicación al Defensor del Pueblo de una de las exigencias procesales marcadas por la LOTC ha sido objeto de cierto debate doctrinal. En este sentido, hay que recordar que el recurso de amparo ante el Tribunal Constitucional ha sido configurado por la LOTC como un recurso subsidiario, que sólo procede una vez que se han agotado todas las vías procesales ordinarias. Sin embargo, esta configuración del recurso de amparo constitucional

130 En este sentido: LUNA ABELLA, C.: op. cit., págs. 740 y ss.; CORDÓN MORENO, F.: op. cit., pág. 132.

131 En este sentido: TORRES MURO, I.: op. cit., págs. 223 yy ss.; aunque el debate sobre este espinoso asunto también se planteó en torno a la intervención de HUET DE SANDE, A.: intervención en el marco de la III Ponencia “Intervención del Defensor del Pueblo en procedimientos jurisdiccionales", en las Jornadas Diez años de la Ley Orgánica del Defensor del Pueblo. Problemas y Perspectivas. Universidad Carlos III de Madrid, Madrid, 1992, págs. 201 y ss.

132 STC 257/1988, FJ 3. En la misma línea: TORRES MURO, I.: op. cit., págs. 223 yy ss.; PÉREZ TREMPS, P.: El recurso de amparo, Tirant, Valencia, 2004, pág. 178; CASCAJO CASTRO, J. L. y GIMENO SENDRA, V.: El recurso de amparo, Tecnos, Madrid, 1992, pág. 111; SÁNCHEZ MORÓN, M.: op.cit., págs. 35 y ss.; ALMAGRO NOSETE, J.: op.cit., págs. 71 y ss.; CORDÓN MORENO, F.: op. cit., pág. 132. 
plantea ciertos problemas para el Defensor del Pueblo, en la medida en que la legislación procesal española atribuye al Defensor del Pueblo legitimación activa ante los tribunales ordinarios en muy contados $\operatorname{casos}^{133}$, de modo que este órgano vería mermadas sus posibilidades de acudir ante el Tribunal Constitucional en amparo al no poder agotar la vía previa por sí mismo, quedando limitadas sus capacidades a que el propio afectado por la medida o el Ministerio Fiscal actúen ante la jurisdicción ordinaria.

Para salvar esta contradicción, la doctrina española ha apuntado dos posibles soluciones. Algunos autores han defendido que el carácter subsidiario del recurso de amparo no sería de aplicación al Defensor del Pueblo, en la medida en que no tendría sentido reconocer legitimación activa en un recurso que se caracteriza como subsidiario a una institución que no está legitimada en las vías judiciales previas ${ }^{134}$. Otra parte de la doctrina ha entendido, argumentando "que quien puede lo más, debe poder también lo menos", que si el Defensor del Pueblo cuenta con legitimación activa para interponer el recurso de amparo debe también contar con legitimación para agotar la vía previa ante los tribunales ordinarios ${ }^{135}$.

Sin embargo, ninguna de las dos propuestas parece poder sostenerse en la actualidad, dada la falta de toda previsión al respecto en la legislación procesal española y en la LOTC y la claridad con la que el Tribunal Constitucional ha reiterado el carácter subsidiario del amparo ${ }^{136}$, de modo que no cabe sino constatar la incoherencia que supone reconocer la legitimación activa en vía de amparo a un órgano que no la tiene en la vía ordinaria cuando el amparo constitucional se configura claramente como un recurso subsidiario ${ }^{137}$. A

133 En concreto, el Defensor del Pueblo está facultado para instar el procedimiento de habeas corpus (art. 3 de la Ley Orgánica 6/1984, de 24 de mayo, reguladora del Procedimiento de Habeas Corpus); para ejercitar la acción de responsabilidad contra las autoridades, funcionarios y agentes civiles del orden gubernativo o administrativo (art. 26 de la Ley Orgánica 3/1981, de 6 de abril, del Defensor del Pueblo); y para interponer el recurso en interés de la Ley, para la unidad de la doctrina jurisprudencial, respecto de las sentencias que resuelvan los recursos extraordinarios por infracción de la ley procesal cuando las Salas de lo Civil y Penal de los TSJ sostuvieran criterios discrepantes de normas procesales (art. 491 de la Ley 1/2000, de 7 de enero, de Enjuiciamiento Civil). Un estudio completo y crítico de la cuestión, puede verse en: LUNA ABELLA, C.: op. cit., págs. 730 y ss

134 En este sentido: MONTORO PUERTO, M.: "Apuntes en torno a la legitimación en algunos procesos constitucionales", Revista de la Administración Publica, núms. 100-102, 1983, págs. 1390 y ss.; FERNÁNDEZ FARRERES, G.: op. cit., pág. 241; CORDÓN MORENO, F.: op. cit., págs. 134135. También parece argumentar en ese sentido, aunque planteando argumentos a favor y en contra: LUNA ABELLA, C.: op. cit., págs. 737 y ss.

135 En este sentido, ver: AGUIAR DE LUQUE, L. y ELVIRA PERALES, A.: "Intervención del Defensor del Pueblo en procedimientos jurisdiccionales", en las Jornadas Diez años de la Ley Orgánica del Defensor del Pueblo. Problemas y Perspectivas. Universidad Carlos III de Madrid, Madrid, 1992, págs. 174 y ss.

136 En el mismo sentido: TORRES MURO, I.: op. cit., pág. 224; ARAGÓN REYES, M.: op. cit., págs. 266-267; PÉREZ TREMPS, P., op. cit., pág. 178.

137 En este sentido: CORCHETE MARTÍN, M. J.: El Defensor del Pueblo y la protección de los derechos, Ediciones Universidad de Salamanca, Salamanca, 2001, págs. 33 y ss.; LUNA ABELLA, C.: op. cit., págs. 735 y ss.; PÉREZ-UGENA y COROMINA, M.: op. cit., págs. 313 y ss. 
pesar de esta constatación, parece interesante analizar la práctica de la institución, esto es, los motivos que han llevado a la misma a interponer apenas 10 recursos de amparo en toda su andadura constitucional, a fin de valorar en qué medida resultaría conveniente resolver este déficit procesal.

\section{IV.3. La Cuestión práctica: ¿Cómo ha utilizado el Defensor del Pueblo LA FACULTAD DE INTERPONER EL RECURSO DE AMPARO?}

Tal y como indicábamos, en la fecha en que concluye este trabajo, el Defensor del Pueblo ha interpuesto un número muy reducido de recursos de amparo, apenas 10 en casi treinta años de existencia, destacando, además, que todos sus recursos fueron interpuestos en los primeros años de funcionamiento de la institución: el último de esos recursos data de 1990, de modo que el Defensor del Pueblo no utiliza la facultad que le atribuye el artículo 162.1.b) de la Constitución desde hace veinte años.

Estos datos parecen exigir una explicación que permita dilucidar qué criterios han sido utilizados por la institución para determinar cuando procedía hacer uso de esa facultad, y si el magro uso que se ha hecho de la misma se debe a su escaso potencial para lograr el objetivo principal de la institución, esto es, la defensa de los derechos reconocidos constitucionalmente, o al problema estructural antes apuntado, que impediría al Defensor del Pueblo aprovechar todas sus potencialidades.

En este sentido, lo primero que interesa destacar son los criterios que parece haber utilizado la institución para decidir sobre la interposición del recurso de amparo. En el primer Informe presentado por el Defensor del Pueblo ante las Cortes Generales ${ }^{138}$, la institución indicaba que dada la amplitud con que la Constitución había reconocido legitimación a los particulares para acudir en amparo ante el Tribunal Constitucional, la institución entendía su facultad como subsidiaria, no pretendiendo sustituir a los propios interesados en el ejercicio de la acción ${ }^{139}$. El Defensor del Pueblo planteaba así la oportunidad de utilizar la facultad tan sólo en aquellos casos en los que tuviera constancia de que la persona afectada no podría recurrir por sus propios medios, pudiendo darse una situación de indefensión, o cuando se hubiera producido una grave violación de los derechos fundamentales con trascendencia en la vida colectiva ${ }^{140}$.

Los criterios así plasmados parecen, desde luego, cabales, en la medida en que permiten a la institución centrar sus esfuerzos en aquellas actividades - como sería el control de la actividad administrativa - menos accesibles para los particulares, a la par que permiten al Defensor accionar el amparo en

138 Defensor del Pueblo, Informe a las Cortes Generales, 1983

139 Ibidem, pág. 21

140 Idem supra. En el mismo sentido: Defensor del Pueblo, Informe a las Cortes Generales, 1986, pág. 584. 
aquellos casos en los que el particular afectado no se encuentre en disposición de ejercer su derecho o en aquellos casos que presenten una trascendencia social o pública que vaya más allá del concreto supuesto de hecho enjuiciado; casos que, dada la tendencia a la objetivación del amparo en nuestro país, serán previsiblemente cada vez más numerosos.

La aplicación de esos criterios, sin embargo, no queda del todo clara en los recursos de amparo que el Defensor del Pueblo ha interpuesto hasta la fecha. En este sentido, es de destacar que el primer recurso de amparo planteado por la institución ${ }^{141}$ fue interpuesto claramente para evitar la eventual indefensión de la parte cuyos derechos podrían haber sido conculcados: la parte no había sido emplazada como demandada en el proceso contenciosoadministrativo previo, de modo que no cumplía con el requisito procesal exigido expresamente por el artículo 46 LOTC, ya que no había sido parte en el proceso judicial previo ${ }^{142}$. A pesar de que la cautela del Defensor del Pueblo parecía innecesaria, dada la amplitud con la que el Tribunal Constitucional ha entendido los requisitos de legitimación previsto en la Constitución española y la LOTC, la intención del Defensor era clara, en la medida en que una vez que el Tribunal Constitucional admitió el recurso interpuesto por la parte afectada, el Defensor del Pueblo desistió de su acción ${ }^{143}$.

No obstante, los motivos por los que el Defensor del Pueblo decidió interponer los otros nueve recursos planteados hasta la fecha no son tan claros, ya que en la mayoría de los supuestos el Defensor no explicaba por qué decidía la interposición del recurso, más allá de señalar que entendía que se había producido la violación de uno de los derechos amparables ${ }^{144}$.

Nada se dice en los Informes anuales de la institución sobre el motivo que llevó al Defensor del Pueblo a plantear hasta siete recursos de amparo ${ }^{145}$

141 Recurso interpuesto el 7 de diciembre de 1983, contra Sentencias de la Sala Tercera del Tribunal Supremo de 7 de octubre de 1983, dictada en el recurso contencioso-administrativo núm. $60695 / 82$ y de la Sala de los Contencioso-Administrativo de la Audiencia Territorial de Valencia de 8 de noviembre de 1982 .

142 En este sentido: Defensor del Pueblo, Informe a las Cortes Generales, 1983, pág. 115.

143 ATC 94/1984, de 15 de febrero, de desistimiento por parte del Defensor del Pueblo.

144 En este sentido, ver: Defensor del Pueblo, Informe a las Cortes Generales, 1986, págs. 34 y ss.; Defensor del Pueblo, Informe a las Cortes Generales, 1987, págs. 21 y ss.; Defensor del Pueblo, Informe a las Cortes Generales, 1990, págs. 26 y ss.

145 Recurso interpuesto el 21 de noviembre, contra Sentencia núm. 513 de la Magistratura de Trabajo de Huelva, de 28 de octubre de 1986, dictada en los Autos 2289/86. Recurso interpuesto el 21 de noviembre, contra Sentencia núm. 514 de la Magistratura de Trabajo de Huelva, de 28 de octubre de 1986, dictada en los Autos 2237/86. Recurso interpuesto el 21 de noviembre, contra Sentencia núm. 515 de la Magistratura de Trabajo de Huelva, de 28 de octubre de 1986, dictada en los Autos 2239/86. Recurso interpuesto el 21 de noviembre, contra Sentencia núm. 516 de la Magistratura de Trabajo de Huelva de 28 de octubre de 1986, dictada en los Autos 2240/86. Recurso interpuesto el 21 de noviembre, contra Sentencia núm. 517 de la Magistratura de Trabajo de Huelva, de 28 de octubre de 1986, dictada en los Autos 2261/86. Recurso interpuesto el 21 de noviembre, contra Sentencia núm. 518 de la Magistratura de Trabajo de Huelva, de 28 de octubre de 1986, dictada en los Autos 2244/86. Recurso interpuesto el 21 de noviembre, contra Sentencia núm. 519 de la Magistratura de Trabajo de Huelva, de 28 de octubre de 1986, dictada en los Au- 
en relación con las sentencias de la Magistratura de Trabajo de Huelva que desestimaron sendas demandas en las que se planteaba que las elecciones sindicales celebradas en distintas empresas de la provincia habían infringido el Estatuto de los Trabajadores, produciéndose un vicio grave, que afectaba al resultado de la elección. El tribunal ordinario desestimó las demandas sin pronunciarse sobre el fondo de la cuestión, al considerar que el demandante no había desarrollado un trámite imprescindible para que pudiera prosperar la acción, en concreto, no había efectuado reclamación o protesta ante la Mesa electoral. El Defensor del Pueblo decidió interponer el recurso de amparo contra esas decisiones, a petición del demandante en el proceso ordinario, al considerar que la legislación vigente podía interpretarse en un sentido más favorable al ejercicio de la acción y que, en caso de que esa interpretación conforme no se estimara adecuada, debía considerarse que la norma que supuestamente imponía tal requisito —un Decreto Legislativo- había sido adoptada por el Gobierno ultra vires, en la medida en que la delegación legislativa que permitió su adopción no le facultaba para imponer esa exigencia procesal.

Tampoco explicaba claramente el Defensor del Pueblo por qué decidió interponer recurso de amparo ${ }^{146}$ contra una Resolución de la Dirección General del Instituto Nacional de Empleo, en la que se denegaba el subsidio de desempleo a un ciudadano por no cumplir un requisito que exigía el Real Decreto 625/1985, de 2 de abril, para acceder a esa prestación; pero que no exigía la Ley 31/1984, de 2 de agosto, de Protección por Desempleo, que regulaba la materia. El Defensor del Pueblo entendía que el establecimiento, en el reglamento de desarrollo de la ley correspondiente, de un requisito para acceder a la prestación no previsto por la norma legal y la aplicación que habrían realizado la Administración y los tribunales de la normativa vigente, sería contraria al derecho de los españoles a ser tratados de forma igual ante la ley, en la medida en que se estaría estableciendo por vía infralegal una diferencia de trato no prevista en la ley y que no tendría base objetiva ni razonable, y por ello, decidió plantear el recurso de amparo. En este asunto destacaba, además, que el recurrente había solicitado el beneficio de la justifica gratuita para poder recurrir ante el Tribunal Constitucional.

Finalmente, tampoco explicaba el Defensor del Pueblo por qué decidió interponer un recurso de amparo ${ }^{147}$ contra el auto de la Sala de lo Social del

tos 2.242/86. Todos estos recursos fueron acumulados y estimados por la STC 178/1987, de 11 de noviembre.

146 Recurso interpuesto el 22 de enero, contra Resolución de la Dirección General del Instituto Nacional de Empleo, de 13 de enero de 1986, confirmada por Sentencia del Tribunal Central de Trabajo de 19 de noviembre de 1986. Este recurso de amparo fue estimado por STC 209/1987, de 22 de diciembre.

147 Recurso de amparo interpuesto el 27 de junio de 1990, contra auto de 23 de mayo de 1990 de la Sala de lo Social del Tribunal Superior de Justicia de Madrid, dictado en el recurso de súplica interpuesto contra auto de la misma Sala de 22 de marzo de 1990. Este recurso de amparo fue estimado por STC 132/1992, de 28 de septiembre. 
Tribunal Superior de Justicia de Madrid que declaró caducado el plazo para la formalización del recurso de súplica contra una sentencia en el marco de un procedimiento sobre reclamación por desempleo. La caducidad del recurso se produjo porque el plazo para su formalización se computó desde el momento en que se anunció el recurso y no desde el momento en que el Letrado de oficio designado para la defensa de los afectados se hizo cargo de los autos, lo que habría vulnerado claramente su derecho a la tutela judicial efectiva sin indefensión.

A pesar de la ausencia de toda explicación al respecto, parece que hay varios elementos que permiten explicar por qué el Defensor del Pueblo habría decidido plantear estos últimos recursos de amparo. En ninguno de los casos la parte afectada interpuso tal recurso, aunque es cierto que el segundo solicitante parecía dispuesto a plantearlo en la medida en que solicitó asistencia jurídica gratuita con esa intención. Además, en los dos primeros asuntos, la queja individual escondía la eventual disconformidad a Derecho de una norma de alcance general, aunque sin rango legal - un Decreto Legislativo adoptado ultra vires, en el primer caso, y un Reglamento, en el segundo-, con lo que la sentencia del Tribunal Constitucional tendría efectos sobre un número potencialmente amplio de afectados. El último de los recursos planteados era quizás más cuestionable, desde este punto de vista, en la medida en que si bien se llamaba la atención sobre la interpretación constitucionalmente adecuada del Texto Refundido de la Ley de Procedimiento Laboral (Real Decreto Legislativo 521/1990, de 27 de abril), la realidad es que la cuestión suscitada no era del todo nueva y se había planteado en ocasiones anteriores ante el Tribunal Constitucional. Claro está, y quizás fuera esa la razón que impulsó al Defensor del Pueblo a plantear su recurso, los recurrentes en el caso concreto habían quedado en una evidente situación de indefensión, que podría haberse consolidado en el caso de que no se hubiera planteado el recurso.

Sin embargo, más allá de los motivos que han llevado al Defensor del Pueblo a plantear los 10 recursos de amparo interpuestos hasta la fecha, también resulta relevante determinar qué motivos han llevado a la institución a no plantear ni un sólo recurso desde el año 1990. En este sentido, lo primero que interesa destacar es que los Informes anuales presentados por el Defensor del Pueblo ante las Cortes Generales no dan cuenta de la existencia de un número excesivamente alto de peticiones de interposición del recurso de amparo. No todos los Informes anuales hacen referencia a la cifra exacta de solicitudes recibidas, pero cuando esta cifra se explicita, el número de solicitudes no supera nunca la cincuentena, haciéndose constar en varios Informes anuales que no se ha presentado solicitud ninguna al respecto ${ }^{148}$ o que las solicitudes presentadas son escasísimas, no llegando siquiera a la dece-

148 En este sentido: Defensor del Pueblo, Informe anual 2003 y debates en las Cortes Generales, Informe, 2004, pág. 1939; Defensor del Pueblo, Informe anual 2004 y debates en las Cortes Generales, Informe, 2005, pág. 1633. 
na ${ }^{149}$. Esta falta de peticiones podría deberse, claramente, a las propias facilidades que ofrece la legislación española para que los particulares afectados interpongan ellos mismos el recurso de amparo ante el Tribunal Constitucional, de modo que antes de solicitar al Defensor del Pueblo su interposición, el particular parece tender a plantear directamente el recurso, al menos en aquellos casos en los que se ha preocupado por agotar la vía previa ante los tribunales ordinarios.

No obstante, este no es el único motivo que parece explicar esa ausencia de recursos, a la luz de los propios Informes presentados anualmente por la institución. En su Informe a las Cortes Generales del año $2007^{150}$, el Defensor del Pueblo subrayaba de forma especialmente incisiva un motivo que explicaba la falta de interposición de este tipo de recursos y que ya se podía rastrear en casi todos sus Informes anteriores. En ese Informe, el Defensor del Pueblo se refería a la "precariedad funcional" en la que quedaba la institución, que debía cumplir todos los requisitos procesales exigidos por la LOTC para plantear el recurso de amparo, pero no tenía legitimación en la vía ordinaria previa, de modo que se veía limitada en la utilización de esta facultad a la diligencia de los particulares en el planteamiento de la cuestión en la vía judicial previa. Para dar una idea del problema que la cuestión representaba para la institución, el Defensor del Pueblo señalaba que, a lo largo del año 2007, se habían recibido 33 solicitudes de recurso de amparo de las cuales tan sólo 4 cumplían los requisitos procesales exigidos por la LOTC.

Es de destacar, claramente, que ese problema no es único del año 2007, ya que en todos los informes anteriores y posteriores de la institución en los que se explicitan los motivos por los que no se ha accedido a las solicitudes de interposición de recursos de amparo se señala de forma clara que muchas de ellas son rechazadas no por motivos de fondo, sino porque las solicitudes que se habían recibido eran extemporáneas, habiendo transcurrido el plazo fijado por la LOTC para interponer el recurso de amparo ${ }^{151}$; porque el quejoso no había agotado la vía judicial previa ${ }^{152}$; o porque no había denunciado la vulneración del derecho fundamental en el marco del proceso tan pronto como se tuvo oportunidad para hacerlo ${ }^{153}$; no cumpliéndose, por tanto, algu-

149 En este sentido: Defensor del Pueblo, Informe anual 2006 y debates en las Cortes Generales, Informe, 2007, pág. 975.

150 Defensor del Pueblo, Informe anual 2007 y debates en las Cortes Generales, Informe, 2008, págs. 1756 y ss.

151 En este sentido, entre muchos otros: Defensor del Pueblo, Informe anual 2009 y debates en las Cortes Generales, 2010, pág. 1729; Defensor del Pueblo, Informe anual 2007 y debates en las Cortes Generales, Informe, 2008, págs. 1756 y ss; Defensor del Pueblo, Informe a las Cortes Generales, 1985, pág. 40; Defensor del Pueblo, Informe a las Cortes Generales, 1984, pág. 235.

152 En este sentido, entre muchos otros: Defensor del Pueblo, Informe anual 2009 y debates en las Cortes Generales, 2010, pág. 1729; Defensor del Pueblo, Informe anual 2008 y debates en las Cortes Generales, Informe, 2009, págs. 1646 y ss.; Defensor del Pueblo, Informe a las Cortes Generales, 1983, pág. 115.

153 En este sentido: Defensor del Pueblo, Informe anual 2009 y debates en las Cortes Generales, 2010, pág. 1729; Defensor del Pueblo, Informe anual 2008 y debates en las Cortes Gene- 
na de las exigencias procesales que impone la LOTC para la interposición del recurso.

Por supuesto, éstos no son los únicos motivos por los que el Defensor del Pueblo señala haber rechazado solicitudes de planteamiento de recursos de amparo. En diversos Informes de la institución, se señala que varias solicitudes se referían a meras cuestiones de legalidad ordinaria o a una simple disconformidad con los hechos declarados probados en el proceso judicial previo $^{154}$ — cuestiones no encajables en el recurso de amparo- o que el Defensor del Pueblo no consideraba viable alguna solicitud por cuestiones de fondo ${ }^{155}$. Sin embargo, es de reseñar que, en muy pocos casos, el Defensor del Pueblo explica públicamente por qué considera inviable una solicitud de planteamiento del recurso de amparo por cuestiones de fondo ${ }^{156}$ y que, en casi ningún informe, se señala de forma clara y diferenciada qué número de solicitudes han sido rechazadas por cuestiones de fondo y cuáles han sido rechazadas por problemas procesales. Los únicos informes que realizan esa distinción de forma nítida son el Informe del año 2007, al que ya nos hemos referido, y el Informe del año $2008^{157}$, en el que se señala que se habían recibido 20 solicitudes de interposición del recurso de amparo, de las cuales tan sólo 1 cumplía los requisitos procesales exigidos por la LOTC. Aunque no consten datos exactos de otros años, parece que los datos de 2007 y 2008 podrían haberse reiterado en años anteriores, de modo que un motivo claro por el que el Defensor del Pueblo no parece estar ejerciendo la facultad que le atribuye el artículo 162.1.b) de la Constitución es que las solicitudes al respecto que recibe no cumplen los requisitos procesales exigidos por la LOTC.

A la luz de estas cifras y dada la configuración del Defensor del Pueblo como uno de los garantes de los derechos constitucionales parece necesario

rales, Informe, 2009, págs. 1646 y ss.; Defensor del Pueblo, Informe anual 2007 y debates en las Cortes Generales, Informe, 2008, págs. 1756 y ss.

154 En este sentido, entre muchos otros: Defensor del Pueblo, Informe anual 2002 y debates en las Cortes Generales, Informe, 2003, pág. 896; Defensor del Pueblo, Informe anual 2001 y debates en las Cortes Generales, Informe, 2002, pág. 704.

155 En este sentido: Defensor del Pueblo, Informe anual 2008 y debates en las Cortes Generales, Informe, 2009, págs. 1646 y ss.; Defensor del Pueblo, Informe anual 2007 y debates en las Cortes Generales, Informe, 2008, págs. 1756 y ss.

156 En este sentido, el Informe a las Cortes Generales de 1987 explicaba con detalle por qué no se había interpuesto recurso de amparo contra una Sentencia del Consejo Supremo de Justicia Militar que condenó al afectado, un Coronel, a cuatro meses de arresto, en aplicación del Código de Justicia Militar. También destaca el detallado análisis que realiza el Informe anual de 1994 en relación con la negativa del Defensor del Pueblo a interponer un recurso de amparo en relación con la decisión de una Comisión de investigación creada en el Congreso de los Diputados de excluir determinadas propuestas de investigación de su plan de trabajo. Finalmente, el Informe del Defensor del Pueblo del año 2008 justifica por qué no se habría accedido a interponer el recurso de amparo contra una sentencia del Tribunal Supremo en materia de protección de datos de carácter personal, habiéndolo solicitado no un particular, sino la Agencia Española de Protección de Datos de Carácter Personal.

157 Defensor del Pueblo, Informe anual 2008 y debates en las Cortes Generales, Informe, 2009, pág. 1646 
replantear la configuración de la legitimación activa del titular de la institución para interponer el recurso de amparo, ya que la actual configuración del recurso de amparo y la legitimación reconocida a la institución para interponerlo no ha servido en absoluto para que desarrolle de forma más eficaz la función que le ha sido atribuida constitucionalmente. Si se considera que la legitimación de esa institución es necesaria para la defensa del interés público que está detrás de ciertos intereses particulares alegados en recursos de amparo y que su actividad puede contribuir a la mejor defensa de ese interés en el marco del proceso de objetivación de ese recurso - planteamiento que comparto- , es necesaria una modificación de la actual legislación española, bien a fin de legitimar al Defensor del Pueblo ante los tribunales ordinarios para que pueda agotar la vía previa cumpliendo los requisitos procesales que exige la LOTC, bien a fin de reconfigurar el recurso de amparo, estableciendo una excepción en cuanto a su carácter subsidiario precisamente en favor de la única institución que, pudiendo interponer el recurso de amparo, no puede agotar la vía ordinaria previa. Si no se comparte esa primera visión, sería quizás conveniente cierta coherencia en el discurso y, por tanto, la eliminación de la legitimación activa del Defensor del Pueblo para interponer el recurso de amparo, ya que dada las cifras que hemos manejado parece evidente que los particulares que agotan la vía previa a la interposición del amparo tienden ellos mismos a plantear ese recurso y que, por tanto, el valor añadido de la legitimación del Defensor estaría precisamente en aquellos casos en los que el particular ni siquiera inicia la vía judicial o por lo menos no la $\operatorname{agota}^{158}$.

\section{A MODO DE CONCLUSIONES}

El reconocimiento al Defensor del Pueblo de legitimación activa para plantear los recursos de amparo e inconstitucionalidad debe ser valorado de forma diferenciada. Si bien entiendo que la atribución al Defensor del Pueblo de legitimación activa para interponer el recurso de inconstitucionalidad se ha realizado de forma excesivamente amplia, máxime si se tiene en cuenta que el constituyente español pareció optar por un modelo de justicia constitucional de acceso notablemente restringido en lo que al control abstracto de la constitucionalidad de las leyes se refiere, considero que la legitimación activa del Defensor del Pueblo para interponer el recurso de amparo se ha desarrollado de forma tan limitada que no puede apenas ser utilizada por la institución a fin de ejercer una tutela más eficaz de los derechos reconocidos en la Constitución.

Efectivamente, el breve estudio de Derecho Comparado realizado muestra que gran parte de los Estados estudiados en los que se reconoce al De-

158 En esa misma línea parecen apuntar también: AGUIAR DE LUQUE, L. y ELVIRA PERALES, A.: op. cit., pág. 168. 
fensor del Pueblo la capacidad de cuestionar la constitucionalidad de las leyes ante la Corte Constitucional respectiva se caracterizan por haber configurado modelos de justicia constitucional de acceso mucho más amplio, en los que la atribución al Defensor del Pueblo de semejante facultad no adquiere el mismo significado político que en nuestro país. Además, en un número importante de esos Estados, la facultad del Defensor del Pueblo de plantear la inconstitucionalidad de las leyes se asocia con el ejercicio de su función como garante de los derechos fundamentales, limitándose el ejercicio de esa facultad a aquellas materias respecto de las cuales parece justificada la intervención del Defensor del Pueblo. En esta lógica, la amplitud de la facultad atribuida al Defensor del Pueblo español parece excesiva en la medida en que no se justifica ni por las funciones que le han sido atribuidas constitucionalmente, ni por la propia configuración de la institución, que no parece haber sido pensada para convertirse en una suerte de guardián de la Constitución al estilo estonio, ni como un representante de los ciudadanos a estos efectos.

En un sentido diametralmente distinto, parece claro que la legitimación activa del Defensor del Pueblo para interponer el recurso de amparo se ubica en el contexto de las funciones que le han sido atribuidas por la Constitución y se justifica por la defensa del interés público objetivo que subyace en ciertos procesos de amparo y que adquirirá mayor relevancia gracias a la objetivación del amparo puesta en marcha tras la aprobación de la Ley Orgánica 6/2007, de 24 de mayo, por la que se modificó la LOTC. Sin embargo, la atribución al Defensor del Pueblo de ese importante instrumento para la defensa de los derechos fundamentales no parece sino haber quedado en una mera declaración de intenciones del constituyente, en la medida en que la actual configuración del amparo como un recurso subsidiario y la imposición al Defensor del Pueblo de la exigencia de agotar la vía judicial previa cuando la institución no está legitimada activamente para actuar ante la jurisdicción ordinaria sino en supuestos muy tasados, parece estar en el origen del escaso uso que ha realizado la Defensoría de la facultad que le atribuye el artículo 162.1.b) de la Constitución. En esa lógica, si se quiere dotar a la institución de un instrumento efectivo habría que pensar en la posibilidad de legitimar al Defensor del Pueblo ante los tribunales ordinarios para que pueda agotar la vía previa o en reconfigurar el recurso de amparo, estableciendo una excepción en cuanto a su carácter subsidiario a favor de la institución.

\section{TITLE: The Spanish Ombudsman and the Constitutional Justice.}

ABSTRACT: The Spanish Ombudsman has been conceived as an institutional guarantee of the fundamental rights recognized in the Spanish Constitution. To protect the fundamental rights of $\mathrm{ci}$ tizens, this institution has been granted the traditional instruments used by other Ombudsmen. Therefore, the Spanish Constitution expressly provides that the Ombudsman is able to control the Administration and will report about its activities to the Parliament. However, the Spanish Ombudsman was gifted with two powers that are not always granted to Ombudsmen, as he/she can 
initiate a proceeding before the Constitutional Court if he/she considers that a law is unconstitutional or if he/she considers that an individual act violates those fundamental rights recognized in articles 14 to 29 and 30.2 of the Spanish Constitution. This paper will focus on those powers, analysing the reasons that leaded the Spanish constituency to grant the Ombudsman powers to initiate some proceedings before the Constitutional Court; the constitutional and legal configuration of those powers; and the use that the Spanish Ombudsman has made of them.

RESUMEN: El Defensor del Pueblo español ha sido concebido como órgano de garantía de los derechos fundamentales reconocidos en el Título I de la Constitución, para lo que podrá controlar la actividad de las administraciones públicas españolas, dando cuenta de su actividad a las Cortes Generales. Más allá de esas facultades, comunes a la mayoría de las instituciones del mismo tipo, la Constitución española le atribuye la facultad de interponer los recursos de amparo y de inconstitucionalidad ante el Tribunal Constitucional. El presente trabajo pretende centrar su atención en esas atribuciones, realizando una valoración crítica de las mismas a partir de otras experiencias constitucionales; del análisis de los motivos que justificaron la atribución de esas facultades a nuestro Defensor del Pueblo; de la configuración constitucional y legal de las mismas; $y$ del uso que de ellas ha hecho el Defensor del Pueblo español.

KeY wORDS: Spanish Ombudsman. Constitutional Justice. Proceeding on the constitutionality of statutes (recurso de inconstitucionalidad). Constitutional complaint (recurso de amparo).

Palabras clave: Defensor del Pueblo. Justicia Constitucional. Recurso de inconstitucionalidad. Recurso de amparo.

FECHA DE RECEPCIÓN: 30.06.2010. FECHA DE ACEPTACIÓN: 28.07.2010. 